\title{
Pharmaceuticals, Personal Care Products, and Endocrine Disruptors in Water: Implications for the Water Industry
}

\author{
Shane A. Snyder, ${ }^{1, *}$ Paul Westerhoff, ${ }^{2}$ Yeomin Yoon, ${ }^{2}$ and David L. Sedlak ${ }^{3}$ \\ ${ }^{1}$ Department of Research and Development \\ Southern Nevada Water Authority \\ Boulder City, NV 89005 \\ ${ }^{2}$ Department of Civil and Environmental Engineering \\ Arizona State University \\ Tempe, AZ 85287 \\ ${ }^{3}$ Department of Civil and Environmental Engineering \\ University of California \\ Berkeley, CA 94720
}

\begin{abstract}
For over 70 years, scientists have reported that certain synthetic and natural compounds could mimic natural hormones in the endocrine systems of animals. These substances are now collectively known as endocrine-disrupting compounds (EDCs), and have been linked to a variety of adverse effects in both humans and wildlife. More recently, pharmaceuticals and personal care products (PPCPs) have been discovered in various surface and ground waters, some of which have been linked to ecological impacts at trace concentrations. The majority of EDCs and PPCPs are more polar than traditional contaminants and several have acidic or basic functional groups. These properties, coupled with occurrence at trace levels (i.e., $<1$ $\mu \mathrm{g} / \mathrm{L})$, create unique challenges for both removal processes and analytical detection. Reports of EDCs and PPCPs in water have raised substantial concern among the public and regulatory agencies; however, very little is known about the fate of these compounds during drinking and wastewater treatment. Numerous studies have shown that conventional drinking and wastewater treatment plants can not completely remove many EDCs and PPCPs. Oxidation with chlorine and ozone can result in transformation of some compounds with reactive functional groups under the conditions employed in water and wastewater treatment plants. Advanced treatment technologies, such as activated carbon and reverse osmosis, appear viable for the removal of many trace contaminants including EDCs and PPCPs. Future research needs include more detailed fate and transport data, standardized analytical methodology, predictive models, removal kinetics, and determination of the toxicological relevance of trace levels of EDCs and PPCPs in water.
\end{abstract}

Key words: endocrine disruptor; pharmaceutical; drinking water; wastewater; treatment; review

\section{ENDOCRINE DISRUPTING COMPOUNDS}

$\mathbf{P}$ ERhaps the most Difficult part of understanding the subject of endocrine disruption involves a definition of the term. The Environmental Protection Agency (EPA) has defined environmental endocrine disrupting compounds (EDCs) as exogenous agents that interfere with the "synthesis, secretion, transport, binding, action, or elimi-

*Corresponding author: Department of Research and Development, Southern Nevada Water Authority, 243 Lakeshore Road, Boulder City, NV 89005. Phone: 702-567-2317; Fax: 702-567-2085; E-mail: shane.snyder@lvvwd.com 
nation of natural hormones in the body that are responsible for the maintenance of homeostasis, reproduction, development, and/or behavior" (EPA, 1997). However, definitions and opinions on what defines an EDC vary greatly. It is generally accepted that the three major classes of endocrine disruption endpoints are estrogenic (compounds that mimic or block natural estrogen), androgenic (compounds that mimic or block natural testosterone), and thyroidal (compounds with direct or indirect impacts to the thyroid). As we will illustrate, the majority of research thus far has focused only on estrogenic compounds; however, disruption of androgen and thyroid function may be of greater or equal importance biologically.

Although the topic of endocrine disruption is considered an "emerging issue" in the water industry, scientists have known about the ability of natural and synthetic compounds to interfere with the hormone systems of animals for over 70 years. The discovery that certain compounds can mimic the endogenous hormones of animals was reported as early as the 1930s (Cook et al., 1934; Walker and Janney, 1930). In 1940, Stroud reported that certain synthetic chemicals were estrogenic (Stroud, 1940). An article from the journal Science published in 1946 explained that the molecular configurations of natural and synthetic compounds influenced the degree of estrogenic and androgenic bioactivity in rodents (Schueler, 1946). The ability of estrogenic and androgenic compounds to interfere with the natural metamorphosis of amphibians was reported as early as 1948 (Sluczewski and Roth, 1948). These early papers began to describe how the molecular configurations of natural and synthetic compounds could mimic the primary endogenous female hormone $17 \beta$-estradiol (E2) and the male hormone testosterone. More importantly, these early studies laid the foundation for how these hormone-mimicking compounds could result in reproductive toxicity. Figure 1 provides the structures for some estrogenic compounds.

The estrogenic activity of synthetic organic compounds was of little interest to the environmental community until the discovery that the organochlorine pesticide, DDT and its metabolites had endocrine-disrupting properties (Fisher et al., 1952; Bitman et al., 1968; Welch et al., 1969; Bitman and Cecil, 1970; Wrenn et al., 1970). The connection between endocrine disruption and reproductive failures in wildlife was not made until the 1980s, when it was reported that gulls living in areas contaminated with DDT exhibited deformed sex organs and skewed sex ratios (Fry and Toone, 1981; Fry et al., 1987). This was one of the first docu-

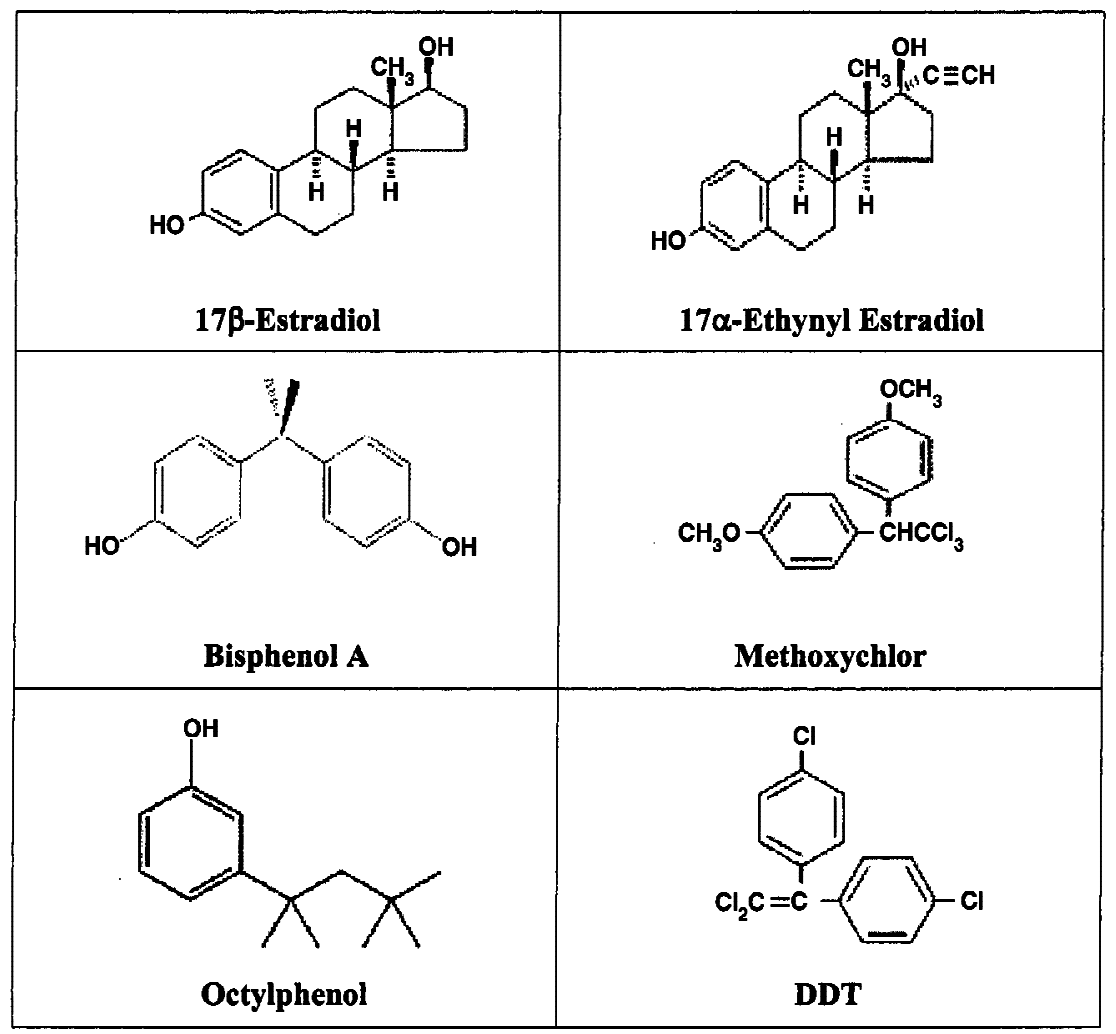

Figure 1. Structures of estrogenic compounds. 
mented connections between an environmental contaminant and reproductive impacts via a hormone-mediated mechanism. Possible links between organochlorine pesticides, including DDT and its metabolites, and endocrine disruption were provided by researchers in Florida, who discovered reproductive disorders in alligators in Lake Apopka (Guillette et al., 1994, 1996).

More recent studies have further demonstrated the importance of endocrine disruption in wildlife populations. For example, marine gastropods exposed to tributyltins, which leach from certain antifouling paints and PVC pipes, experienced severe population declines and reproductive disorders including imposex (development of male sex characteristics in females) (Gibbs et al., 1991). In some amphibian populations, supernumerary limbs and missing limbs have been attributed to certain pesticides and other anthropogenic chemicals (Ouellet et al., 1997; Sparling, 2000). In particular, trace concentrations of the widely used herbicide atrazine have been associated with endocrine disruption in frogs from the Midwestern United States (Hayes et al., 2002). Degradation products from the widely used alkylphenol polyethoxylate (APE) surfactants, which are ubiquitous contaminants of wastewater treatment plant effluents, have been shown to be estrogenic (Mueller and Kim 1978; White et al, 1994; Routledge and Sumpter 1997; Giesy et al., 2000) and bioaccumulative (Ahel et al., 1993; Liber et al., 1999; Lye et al., 1999; Snyder et al., 2001a). In the 1990s, reports from the United Kingdom and the United States indicated that fish living below wastewater treatment plants had several reproductive abnormalities (Bevans et al., 1996; Folmar et al., 1996; Harries et al., 1996; Purdom et al., 1994; Jobling et al., 1998). These reproductive abnormalities included changes in the levels of sex steroids, gonadal histology (e.g., hemaphrodism and intersex), and increased levels of the female egg yolk precursor, vitellogenin, in male fish. Collectively, these impacts of wastewater effluent on male fish are referred to as feminization because fish that are genetically male exhibit female sex characteristics. However, conclusive data linking population level impacts on fish from EDC exposures has not yet been published. There are many other examples of exogenous compounds acting as EDCs, and more EDCs will likely be discovered as screening and testing methods become available.

Endocrine disruption also can be caused by naturally occurring compounds. For example, estrogens from plant sources, known as phytoestrogens, have been linked to reproductive failures in animals since the 1930s (Walker and Janney, 1930; Levin et al., 1951; Brookbanks et al., 1969; Metzler and Pfeiffer, 1995; Safe and Gaido, 1998). This effect was evident in sheep grazing on certain strains of clover in New Zealand. These sheep exhibited severe reproductive impairment due to phytoestrogens (Millington et al., 1964; Adams, 1998). Likewise, the inability of captive cheetahs to reproduce at the Cincinnati Zoo was linked to a diet high in phytoestrogens (Setchell et al., 1987). In 1951, a vegetable oil was found to contain various phytoestrogens and phytoandrogens (Levin et al., 1951). Interestingly, various over-thecounter medicinal supplements, such as those recommended for estrogen replacement therapy in postmenopausal women, contain high levels of phytoestrogens. Research is necessary to assess the relative importance of phytoestrogens in human diet, both by direct ingestion of vegetables and vegetable products and possibly from bioaccumulation of phytoestrogens in meat products. Likewise, industrial activities that release large quantities of phytoestrogens may have adverse effects on aquatic ecosystems as evidenced by recent studies documenting masculinization of fish exposed to effluent from pulp and paper mills and the presence of androgenic compounds in these effluents (Munkittrick et al., 1997; Bortone and Cody, 1999; Larsson et al., 2000; Jenkins et al., 2001). Likewise, the degradation of vegetable matter and paper products in wastewater treatment plants (WWTPs) may contribute to releases of phytoestrogens into the aquatic ecosystem.

Initial attempts to identify the cause of feminization of fish exposed to wastewater effluent focused on synthetic organic chemicals with known estrogenic effects, such as plasticizers and APE surfactant degradation products. However, a series of studies employing in vitro bioassaydirected chemical fractionation implicated the human hormone, $17 \beta$-estradiol (E2), and the synthetic birth control pharmaceutical, $17 \alpha$-ethinyl estradiol (EE2), as the most potent estrogens in these complex mixtures (Desbrow et al., 1998; Snyder et al., 1999, 2001c). Related research involving exposure of fish to E2 and EE2 under laboratory conditions at concentrations as low as $2 \mathrm{ng} / \mathrm{L}$ could induce measurable changes in fish reproduction (ArcandHoy et al., 1998; Kramer et al., 1998; Panter et al., 1998; Routledge et al., 1998). These reports indicated that a pharmaceutical (EE2) could induce endocrine-disruptive effects in fish at concentrations present in some municipal WWTP effluents. This cause-effect relationship has stimulated a great deal of new research on the identification of trace pharmaceuticals in the environment.

The unexpected impacts of trace concentrations of EDCs on wildlife raised concerns about the potential effects of these chemicals on humans (Colborn et al., 1997). The best documented instance of endocrine disruption in humans involved in utero exposure to the potent synthetic estrogen diethylstilbestrol (DES), which resulted in adverse reproductive impacts in human offspring (Herbst $e t$ al., 1971; Gill et al., 1979). In this case, DES exposure 
was not as an environmental contaminant; it was used as a pharmaceutical administered to pregnant women (Sower et al., 1983; Rumsey and Hammond, 1990). However, the unanticipated sensitivity of the developing human reproductive system to DES clearly demonstrates that the human embryo/fetus is not immune to insult by exogenous chemicals that act as hormones. Besides usage as a human pharmaceutical, DES is also used for certain agricultural applications such as increasing livestock growth and milk production.

Some researchers have attributed decreases in human sperm quality and quantity over the past 5 decades to endocrine disrupting compounds in the environment (Sharpe and Skakkebaek, 1993; Stone, 1994; Carlsen et al., 1995). Likewise, it has been suggested that sharp increases in breast, testicular, and prostate cancers reported over the past 40 years are related to endocrine disrupting compounds in the environment (Krishnan and Safe, 1993; Ahlborg et al., 1995; Carlsen et al., 1995; Ashby, 1997; EPA, 1997; Gillesby and Zacharewski, 1998). However, this topic is still quite controversial, and other scientists have produced data refuting these arguments. If EDCs are causing adverse human health effects, it is unlikely that these effects would be caused by estrogenic chemicals in water due to their extremely minute concentrations that result in doses that are small compared to phytoestrogens and other estrogenic compounds present in food sources. Estrogenic hormones in water are less likely to cause adverse effects in humans than they are in fish due to differences in exposures. Although fish may be constantly exposed to EDCs present in the aquatic environment, humans are exposed mainly through ingestion of limited quantities of water.

In addition to compounds capable of eliciting estrogenic activity, concerns have been raised regarding human health effects associated with pollutants that interact with other hormone systems. Recently, a great deal of public and regulatory interest has focused on perchlorate $\left(\mathrm{ClO}_{4}{ }^{-}\right)$, which affects the thyroid gland by competitively inhibiting iodide transport (Urbansky, 2000; Logan, 2001). Ammonium perchlorate is a strong oxidizer that has been used extensively in solid-rocket fuels, fireworks, matches, and other industrial and domestic uses (Urbansky, 2000). Nearly every state in the United States has known perchlorate use, storage, or manufacturing sites, and perchlorate contamination has recently been found in many ground and surface waters (Wang et al., 2002). Perchlorate salts were also used as a pharmaceutical to treat overactive thyroid disease and continue to be used to treat side effects of certain chemotherapy drugs (Wang et al., 2002). Because perchlorate has a direct impact on the thyroid, it is considered an EDC, and will likely become the first drinking water contaminant regulated on endocrine disrupting toxicity, as the U.S. EPA is currently establishing a reference dose.

Some scientists have suggested that some drinking water disinfection byproducts (DBPs) may act as EDCs. Several reports, which include epidemiological studies, have reported increases in spontaneous abortions and cancers in humans as linked to elevated concentrations of halogenated disinfection byproducts (King and Marrett, 1996; King et al., 2000a, 2000b). Additionally, the Endocrine Disruptor Screening and Testing Advisory Committee (EDSTAC), a Federal Advisory Committee, suggested that DBPs should be included among the mixtures to be evaluated for endocrine disruptive effects (EPA, 1998). Because DBPs generally are orders of magnitude greater in concentration than EDCs and pharmaceutical and personal care products (PPCPs), and have been implicated as human reproductive toxicants, efforts to control EDCs and PPCPs by oxidation ultimately may prove to be counterproductive due to increased byproduct formation potential.

\section{PHARMACEUTICALS AND PERSONAL CARE PRODUCTS (PPCPs)}

The first concerns regarding potential adverse effects of pharmaceuticals in municipal wastewater were expressed by Stumm-Zollinger and Fair in 1965 and Tabak and Bunch in 1970 (Stumm-Zollinger and Fair, 1965; Tabak and Bunch, 1970). In their visionary, but largely forgotten study of the biotransformation of estrogenic hormones by activated sludge, they noted that natural and synthetic estrogens could pose an ecological threat. Other studies conducted in the United States during the 1970s documented the presence of other pharmaceuticals, such as clofibric acid and salicylic acid in wastewater effluents (Garrison et al., 1975; Hignite and Azarnoff, 1977). Later studies have shown that natural and synthetic estrogens are ubiquitous contaminants of wastewater at trace concentrations (Tabak et al., 1981; Aherne et al., 1985; Desbrow et al., 1998; Lee and Peart, 1998; Snyder et al., 1999; Huang and Sedlak, 2001). However, reports demonstrating the possible impacts of trace levels (ng/L) of the pharmaceutical EE2 (Arcand-Hoy et al., 1998; Desbrow et al., 1989; Renner, 1998; Snyder et al., 2001c) have stimulated a dramatic increase in research on these compounds as environmental contaminants (Halling-Sorensen et al., 1998; Daughton and Ternes, 1999; Snyder et al., 2001a). A wide variety of PPCPs have now been reported as environmental contaminants including antibiotics, X-ray contrast media, analgesics, antiseptics, and many others (Halling-Sorensen et al., 1998; Daughton and Ternes, 1999). In the United States, 
a recent survey indicated widespread PPCP contamination of streams (Kolpin et al., 2002). Table 1 shows several of the most frequently detected EDCs and PPCPs along with concentration, usage, and structural information. Unfortunately, sparse data exist to explain the toxicological relevance of trace pharmaceutical compounds. Nevertheless, public perception regarding the presence of PPCPs in water supplies has increased attention to this issue despite the very low concentrations reported.

\section{U.S. REGULATORY ISSUES}

In the United States, regulation of contaminants in drinking water began in 1962, with the Public Health Services Standards. These regulations included several compounds now known to be endocrine disruptors, such as arsenic, cadmium, and some phenols. The Safe Drinking Water Act of 1974 is the principal law governing drinking water safety in the United States. This law required the EPA to establish maximum contami- nant levels for various drinking water contaminants including some pesticides now known to have endocrinedisruptive activity. However, endocrine disruption was not specifically named in any United States legislation until 1995 with amendments to the Safe Drinking Water Act (bill number S.1316) and Food Quality Protection Act (bill number P.L. 104-170), mandating that chemicals and formulations be screened for potential endocrine activity before they are manufactured or used in certain processes where drinking water and/or food could become contaminated. Under these laws, the EPA is required to "develop a screening program, using appropriate validated test systems and other scientifically relevant information, to determine whether certain substances may have an effect in humans that is similar to an effect produced by a naturally occurring estrogen, or other such endocrine effect as the Administrator may designate." Furthermore, these laws specify that the EPA must have developed a testing program by 1998 , implemented the program by 1999 , and reported to Congress by 2000 .

Table 1. Compounds with highest frequency of detection in recent USGS EDC/PPCP survey of U.S. streams (Kolpin et al., 2002).

\begin{tabular}{|c|c|c|c|}
\hline Compounds & Use & $\begin{array}{l}\text { Frequency of detection } \\
(\%)\end{array}$ & $\begin{array}{l}\text { LogKow,measured } \\
\text { (calculated })\end{array}$ \\
\hline Coprostanol & Estrogen & $\sim 80 \%$ & $(8.82)$ \\
\hline Cholesterol & Plant/animal steroid & $\sim 80 \%$ & $(8.74)$ \\
\hline N-N-diethyltoluamide & Mosquito repellant & $\sim 80 \%$ & $2.18(2.26)$ \\
\hline Caffeine & Stimulant & $\sim 75 \%$ & $-0.07(0.16)$ \\
\hline Tris(2-chloroethyl)phosphate & Fire retardant & $\sim 75 \%$ & $1.44(1.63)$ \\
\hline Triclosan & Antibiotic & $\sim 60 \%$ & NA \\
\hline 4-Nonylphenol & Surfactant & $\sim 60 \%$ & $(5.92)$ \\
\hline 4-Nonylphenol monoethoxylate & Surfactant & $\sim 50 \%$ & NA \\
\hline Ethanol, 2-butoxy-phosphate & Plasticizer & $\sim 45 \%$ & NA \\
\hline 4-Octylphenol monoethoxylate & Surfactant & $\sim 45 \%$ & NA \\
\hline Bisphenol A & Plasticizer & $\sim 45 \%$ & $3.32(3.64)$ \\
\hline Cotinine & Nicotine metabolite & $\sim 35 \%$ & $0.07(0.34)$ \\
\hline 4-Nonylphenol diethoxylate & Surfactant & $\sim 35 \%$ & NA \\
\hline 5-Methyl-1H-benzotiazole & Antioxidant & $\sim 30 \%$ & NA \\
\hline Fluoranthene & $\mathrm{PAH}$ & $\sim 30 \%$ & $5.16(4.93)$ \\
\hline 1,7,-Dimethylxanthine & Caffeine metabolite & $\sim 30 \%$ & $-0.22(-0.39)$ \\
\hline Pyrene & PAH & $\sim 25 \%$ & $4.88(4.93)$ \\
\hline Trimethoprim & Antibiotic & $\sim 25 \%$ & NA \\
\hline 1,4-Dichlorobenzene & Deodorizer & $\sim 25 \%$ & $3.44(3.28)$ \\
\hline Acetaminophen & Analgesic & $\sim 25 \%$ & $0.46(0.27)$ \\
\hline Tetrachloroethylene & Solvent & $\sim 20 \%$ & NA \\
\hline 4-Octylphenol diethoxylate & Surfactant & $\sim 20 \%$ & NA \\
\hline Erythromycin- $\mathrm{H}_{2} \mathrm{O}$ & Antibiotic & $\sim 20 \%$ & NA \\
\hline Estriol & Estrogen & $\sim 20 \%$ & $2.45(2.81)$ \\
\hline Lincomycin & Antibiotic & $\sim 15 \%$ & $0.59(0.29)$ \\
\hline Sulfamethoxazole & Antibiotic & $\sim 15 \%$ & $0.89(0.48)$ \\
\hline Phthalic anhydride & Plasticizer & $\sim 15 \%$ & $1.60(2.07)$ \\
\hline Carbaryl & Insecticide & $\sim 15 \%$ & NA \\
\hline
\end{tabular}


To meet the requirements of this recent legislation, the EPA formed the EDSTAC to provide recommendations on a conceptual framework, priority setting, screening, and testing methodologies, and communication and outreach programs. The EDSTAC group consisted of various stakeholders and experts in reproductive toxicology. The committee began deliberations in October of 1996 and issued a final report in July of 1998 recommending that human and wildlife impacts be considered, and that estrogen, androgen, and thyroid (EAT) end points be examined (EPA, 1998). The conceptual framework devised by EDSTAC consists of an initial sorting, prioritization, Tier 1 and 2 testing, and a hazard assessment of an estimated 87,000 chemicals. In addition to discrete chemicals, EDSTAC recommended the evaluation of mixtures of chemicals in breast milk, baby formulas, hazardous waste sites, pesticides and fertilizers, drinking water DBPs, and gasoline.

In 2001, the EPA formed the Endocrine Disruptor Methods Validation Subcommittee (EDMVS) to evaluate the test battery suggested by EDSTAC. The EDMVS is tasked with method validation by determining if a particular method is transferable to other laboratories, can be validated with representative chemicals, has sufficient sensitivity to EAT end points, and has appropriate standard operating procedures. Some difficult issues encountered in the standardization of EDC testing include animal diets, dosing methods and ranges, testing of mixtures, and interspecies comparisons. The outcome of this screening battery is critical to the water industry, as it designed to definitively identify EDCs. However, it is important to note that the current legislation regulates only the industries producing or using raw chemicals, and not the water industry. As a result, these actions may have little immediate effect on water and wastewater treatment regulations.

There are currently no federal regulations for pharmaceuticals in drinking or natural waters. The Food and Drug Administration (FDA) requires ecological testing and evaluation of a pharmaceutical only if an environmental concentration in water or soil is expected to exceed $1 \mu \mathrm{g} / \mathrm{L}$ or $100 \mu \mathrm{g} / \mathrm{kg}$, respectively (FDA, 1998). In light of the recent data on the occurrence of PPCPs in the aquatic environment, these policies may need to be reconsidered. Although extensive monitoring programs are underway, toxicological studies conducted at environmentally relevant concentrations are necessary for intelligible regulations to be established. The State of California has been considering the potential impacts of EDCs and PPCPs, especially when municipal wastewater effluent is used for indirect potable reuse. A recent modification to California's draft regulations for indirect potable reuse states, "Each year, the PGRRP [planned groundwater recharge reuse project] shall monitor the recycled water for endocrine disrupting chemicals and pharmaceuticals specified by the Department, based on a review of the PGRRP engineering report and the affected groundwater basin(s)." Although the regulations have not been finalized, many practitioners of indirect potable reuse in California are establishing monitoring program for EDCs and PPCPs. Because California's water reuse program often establishes precedents for programs throughout the world, it is likely that other regulatory agencies will adopt similar language in their own water recycling programs.

\section{ANALYTICAL METHODS}

Because EDCs represent a broad variety of compounds, it is important to define which EDCs one seeks to analyze. It is widely accepted that DDT and other organochlorine pesticides can act as EDCs. Methodologies for these "classic" contaminants, as well as various endocrine-disrupting metals, are well established with standardized protocols used in drinking and wastewater regulations. The majority of novel analytical work is focused on trace levels of less-characterized contaminants with greater polarity than many of the "classic" contaminants. Several classes of EDCs and PPCPs have acidic or basic moieties, large molecular weights, and/or polar functional groups. No standard methods are currently available for these compounds, and few commercial laboratories analyze these compounds. A further complication is the desire to quantitate these compounds at ultratrace concentrations (sub-ng/L), which may have toxicological relevance (e.g., EE2).

A vast array of analytical methodologies has been applied for the quantitation of EDCs and PPCPs in water. Although direct measurement is possible (Yoon et al., 2003), the majority of methods involve an extraction procedure followed by instrumental and/or immunoassay analyses (Tabak and Bunch, 1970; Keith et al., 1975; Hignite and Azarnoff, 1977; Aherne et al., 1985; Shore et al., 1993; Ternes et al., 1998; Snyder et al., 1999, 2001 a; Stumpf et al., 1999; Heberer and Dumnbier, 2000; Huang and Sedlak, 2001). The type of extraction, volume of water used, and type of analytical equipment used depend on the compounds to be analyzed and source of water. For instance, WWTP effluents are the major source of these compounds to surface waters. The analysis of WWTP effluents provides unique challenges for trace quantification because the effluent also contains numerous interfering compounds associated with organic matter. Consequently, extensive extraction, cleanup, and sophisticated instrumentation usually is required to ana- 
lyze these compounds. Several methodologies for quantitation of EDCs and PPCPs in natural waters used solidphase extractions followed by instrumental analyses using gas chromatography coupled with mass spectrometric detection, liquid chromatography with mass spectrometric detection, immunoassays, or a combination of techniques (Keith et al., 1975; Hignite and Azarnoff, 1977; Tabak et al., 1981; Aherne et al., 1985; Shore et al., 1993; Ternes et al., 1998; Snyder et al., 1999, 2001a; Stumpf et al., 1999; Heberer and Dumnbier, 2000; Huang and Sedlak, 2001; Ternes, 2001). Each method has advantages and disadvantages, detailed descriptions of which are outside the scope of this paper.

Bioanalytical techniques are important tools for monitoring certain EDCs and PPCPs. These techniques employ a biological end point that is related to a type of toxicity or a class of compounds. The most simple methods are receptor binding assays and cellular bioassays that have rapid response times, high sensitivity, and relativity low cost (Welch et al., 1969; Mueller and Kim, 1978; Anderson et al., 1996; Routledge and Sumpter, 1997; Zacharewski, 1997; Snyder et al., 2000, 2001c). In vivo bioassays are also used to detect various classes of EDCs. The most common biomarker for estrogenic exposure in the aquatic environment is an increase in plasma vitellogenin (an egg yolk lipid) in male fish. Fish can be caged in various susceptible waters and tested for various endocrine biomarkers to determine the extent of EDC exposure. Several studies of this nature have found significant reproductive impacts in fish caged below wastewater outfalls (Purdom et al., 1994; Rudel, 1997; Routledge et al., 1998; Miles-Richardson et al., 1999; Snyder et al., 2000). Although each instrumental and bioanalytical technique has advantages and disadvantages, a combination of these methods is most likely to detect and quantify EDCs. This approach is often referred to as toxicity identification evaluation, and may use bioassay-directed fractionation to guide instrumental analyses towards elucidation of toxic compounds (Desbrow et al., 1998; Routledge et al., 1998; Castillo and Barcelo, 1999; Snyder et al., 2001c). The issue of mixture toxicity, especially in relation to endocrine disruption, may likely drive the drinking water industry to employ a number of biological monitoring tools. Since all environmental contaminants exist as components of complex mixtures, biological tests may be the only way to assess the total endocrine-disruptive potential of contaminants in water.

\section{EDC/PPCP removal during water treatment}

EDCs and PPCPs in municipal wastewater can be removed during wastewater treatment, during their passage through surface or groundwater (e.g., natural at- tenuation) or during drinking water treatment. To assess the potential for exposure of humans and aquatic organisms to these compounds and to design more effective treatment systems, environmental professionals need to understand the mechanisms through which EDCs and PPCPs are attenuated in engineered and natural systems. The best understood of the treatment processes is conventional wastewater treatment (Ternes, 1998; Ternes et al., 1999a, 1999b; Johnson and Sumpter, 2001). Compared to municipal wastewater treatment plants, much less is known about the behavior of EDCs and PPCPs in receiving waters and in drinking water treatment plants. Therefore, the purpose of this review is to summarize existing data, to predict the behavior of different classes of EDCs and PPCPs based upon chemical properties, and to identify areas where additional research is needed.

Conventional surface water treatment plants (SWTPs) typically treat water via coagulation using alum, ferric chloride, and/or synthetic polymers followed by flocculation, sedimentation, filtration, and disinfection. Conventional SWTPs achieve high removals of pathogens and other biological particles, and modest removal of dissolved organic carbon (DOC, 1 to $10 \mathrm{mg} / \mathrm{L}$ ). In the United States, chlorine and chloramines are typically used for disinfection, while ozonation is more commonly practiced in European countries. Alternative SWTP designs or modifications to conventional WTPs sometimes include additional water treatment processes (e.g., activated carbon, biofiltration, membranes, aeration, chemical softening, ultraviolet light irradiation).

Our understanding of the removal of EDCs and PPCPs in receiving waters and in drinking water treatment systems is limited because the analyses for these compounds are rare, and when detected, they are present at fluctuating concentrations near analytical method detection limits. With a few notable exceptions, most of our knowledge about the removal of these compounds is derived from laboratory or bench-scale studies. When data on removal of EDCs and PPCPs are not available, it may be possible to make predictions based upon results of previous research with contaminants exhibiting similar chemical properties.

As a result of much evidence linking estrogenic hormones to endocrine disruption in fish, there has been a great deal of interest in the fate of E2, EE2, and nonylphenol ethoxylates (NPEs) in surface waters. For example, laboratory studies designed to simulate microbial transformation of NPEs in surface waters indicate that they are degraded in 4 days (Mann and Boddy, 2000), which is consistent with the observation of a relatively small decrease in concentrations when nitrified wastewater effluent passes through an engineered treatment wetland. 
Studies conducted at a drinking water treatment plant along the Severn Trent Region, a system with significant inputs of wastewater effluent, indicate that estrogenic hormones and other compounds capable of producing estrogenic effects in bioassays are removed during drinking water treatment (Fawell et al., 2001).

The attenuation of PPCPs in receiving waters and in drinking water treatment plants also has been demonstrated in several studies and has been reviewed recently (Heberer, 2002). For example, the attenuation of several PPCPs was observed as secondary wastewater effluent was infiltrated into groundwater (Drewes et al., 2001a) and during river bank filtration (Heberer, 2002). However, certain compounds, such as the iodinated X-ray contrast media were not removed during groundwater infiltration (Putschew et al., 2000). In contrast to the efficient removal of many PPCPs observed in saturated and unsaturated groundwater, conventional drinking water treatment plants do not appear to remove PPCPs well. For example, clofibric acid has been detected at concentrations as high as $270 \mathrm{ng} / \mathrm{L}$ in drinking water from Berlin (Heberer and Dumnbier, 2000). Of 47 wastewater tracers and EDCs analyzed, 15 were detected in raw drinking water (river water) samples, and 14 in finished drinking water samples from Atlanta (Henderson et al., 2001). In that study, caffeine was present in all raw waters and some finished waters. Although all at trace concentra- tions (ng/L), the following compounds were detected in finished drinking waters: tri(2-chloroethyl)phosphate, phthalic anhydride, triclosan, fluoranthene, pyrene, 2,6d-t-butylphenol, thanol-2-butoxy-phosphate, and tributyl phosphate. Caffeine, cotinine, and acetaminophen were also detected in the finished drinking water (Henderson et al., 2001).

Although monitoring studies involving low concentrations of EDCs and PPCPs provide insight into the occurrence of these compounds in the environment, previously discussed issues associated with method detection limits and dilution factors complicate the analysis of monitoring data. As a result, more insight into removal processes can be obtained by examining specific treatment processes. Table 2 represents anticipated performance of different unit processes based upon literature reports with specific classes of compounds or compounds with similarities to other trace pollutants that have been studied in more detail. The following sections describe the potential for common water treatment processes to remove EDCs or PPCPs.

\section{Chemical precipitation processes}

Metal salts (aluminum sulfate, ferric chloride) and softening chemicals (calcium oxide, sodium carbonate) are commonly added to destabilize particles present in

Table 2. Unit processes and operations used for EDCs and PPCPs removal.

\begin{tabular}{|c|c|c|c|c|c|c|c|c|c|c|c|}
\hline Group & Classification & $A C$ & $B A C$ & $\mathrm{O}_{3} / \mathrm{AOPs}$ & $U V$ & $\mathrm{Cl}_{2} / \mathrm{ClO}_{2}$ & $\begin{array}{l}\text { Coagulation/ } \\
\text { flocculation }\end{array}$ & $\begin{array}{l}\text { Softening/ } \\
\text { metal oxides }\end{array}$ & $N F$ & $R O$ & $\begin{array}{c}\text { Degradation } \\
\{B / P / A S\}^{\mathrm{a}}\end{array}$ \\
\hline \multirow[t]{6}{*}{ EDCs } & Pesticides & E & E & L-E & $\mathrm{E}$ & P-E & $\mathrm{P}$ & G & G & E & $E\{P\}$ \\
\hline & Industrial chemicals & $\mathrm{E}$ & $\mathrm{E}$ & F-G & E & $\mathrm{P}$ & P-L & P-L & E & $\mathrm{E}$ & G-E $\{B\}$ \\
\hline & Steroids & E & $\mathrm{E}$ & E & E & $\mathrm{E}$ & $\mathrm{P}$ & P-L & G & E & L-E $\{B\}$ \\
\hline & Metals & G & G & $\mathrm{P}$ & $\mathrm{P}$ & $\mathrm{P}$ & F-G & F-G & G & E & $P\{B\}, E\{A S\}$ \\
\hline & Inorganics & P-L & $\mathrm{F}$ & $\mathrm{P}$ & $\mathrm{P}$ & $\mathrm{P}$ & $\mathrm{P}$ & G & G & E & P-L \\
\hline & Organometallics & G-E & G-E & L-E & F-G & P-F & P-L & P-L & G-E & $\mathrm{E}$ & L-E \\
\hline \multirow[t]{6}{*}{$\mathrm{PhACs}$} & Antibiotics & F-G & $\mathrm{E}$ & L-E & F-G & P-G & $\mathrm{P}-\mathrm{L}$ & P-L & $\mathrm{E}$ & $\mathrm{E}$ & $\begin{array}{c}E\{B\} \\
G-E\{P\}\end{array}$ \\
\hline & Antidepressants & G-E & G-E & L-E & F-G & P-F & P-L & P-L & G-E & E & G-E \\
\hline & Anti-inflammatory & E & G-E & $\mathrm{E}$ & $\mathrm{E}$ & P-F & $\mathrm{P}$ & P-L & G-E & $\mathrm{E}$ & $E\{B\}$ \\
\hline & Lipid regulators & E & E & $\mathrm{E}$ & F-G & $\mathrm{P}-\mathrm{F}$ & $\mathrm{P}$ & P-L & G-E & $\mathrm{E}$ & $\mathrm{P}\{\mathrm{B}\}$ \\
\hline & X-ray contrast media & G-E & G-E & L-E & F-G & $\mathrm{P}-\mathrm{F}$ & P-L & P-L & G-E & $\mathrm{E}$ & $\mathrm{E}\{\mathrm{B}$ and $\mathrm{P}\}$ \\
\hline & Psychiatric control & G-E & G-E & L-E & F-G & P-F & P-L & P-L & G-E & $\mathrm{E}$ & G-E \\
\hline \multirow[t]{4}{*}{ PCPs } & Synthetic musks & G-E & G-E & L-E & E & P-F & $\mathrm{P}-\mathrm{L}$ & P-L & G-E & $\mathrm{E}$ & $\mathrm{E}\{\mathrm{B}\}$ \\
\hline & Sunscreens & G-E & G-E & L-E & F-G & $\mathrm{P}-\mathrm{F}$ & P-L & P-L & G-E & $\mathrm{E}$ & G-E \\
\hline & Antimicrobials & G-E & G-E & L-E & F-G & $\mathrm{P}-\mathrm{F}$ & P-L & P-L & G-E & $\mathrm{E}$ & $\mathrm{F}\{\mathrm{P}\}$ \\
\hline & Surfactants/detergents & E & E & F-G & F-G & $\mathrm{P}$ & P-L & P-L & $\mathrm{E}$ & $\mathrm{E}$ & $\mathrm{L}-\mathrm{E}\{\mathrm{B}\}$ \\
\hline
\end{tabular}

${ }^{a} \mathrm{~B}$, biodegradation; $\mathrm{P}$, photodegradation (solar); AS, activated sludge; E, excellent (>90\%); G, good (70-90\%); F, fair (40-70\%); L, low (20-40\%); P, poor $(<20 \%)$. 
water or to precipitate new particles (coagulation), aggregate particles (flocculation), and improve settling characteristics of particles (clarification). Sand filtration is commonly used after clarification for additional particle removal. Natural organic matter (NOM) and EDCs or PPCPs may adsorb to particles in water and metal hydroxide particles formed during coagulation. Furthermore, chemical precipitation can remove moderately hydrophobic organic contaminants that have a strong affinity for adsorbed NOM (Rebhun and Lurie, 1993). However, very little is known about the association of EDCs or PPCPs to particles present in water treatment systems. Therefore, it is difficult to make a priori predictions about the removal of EDCs or PPCPs during chemical precipitation processes.

Despite these potential shortcomings, considerable insight can be obtained by considering the behavior of pesticides, herbicides, and polycyclic aromatic hydrocarbons (PAHs) during chemical precipitation processes (Eldib and Aly, 1977; Rebhun et al., 1998). Partitioning of organic compounds onto particles can occur through several mechanisms. For hydrophobic compounds, partitioning can be predicted from octanol-water partition coefficients $\left(K_{\mathrm{OW}}\right)$ (Karickhoff and Morris, 1985; Chiou et al., 1998). Under the conditions encountered during water treatment, only those compounds with relatively high $K_{\mathrm{OW}}$ values (i.e., $>10^{5}$ will be removed to an appreciable degree. As indicated in Table 1, most compounds of potential concern are relatively polar $\left(\log K_{\mathrm{OW}}\right.$ values less than 3 ) and as a result, only a few EDCs and PPCPs (e.g., nonylphenol, fluroanthene, pyrene) are expected to be removed during chemical precipitation. Some of the more hydrophobic compounds are present in wastewater effluents, but may not occur in raw drinking water supplies (Henderson et al., 2001). Some surfactants have relatively high $K_{\mathrm{OW}}$ values, but include both polar and nonpolar moieties. The partitioning of octylphenol in English river sediments was greatest to the clay and silt fraction of the sediments, suggesting a hydrophobic interaction with organic carbon as well as surface area associated with the clay and silt particles (Johnson et al., 1998). As a result, only a few compounds (e.g., bisphenol A, E2, EE2, octylphenol, PAHs) could be associated with organic phases of particles in drinking water treatment plants.

In addition to hydrophobic partitioning, organic contaminants can be adsorbed to particles by interactions of polar functional groups with charged particles and mineral surfaces by complexation or ion exchange. For example, the observed sorption of many polar veterinary pharmaceuticals (e.g., tetracycline) to soil and sediment is considerably stronger than predicted by hydrophobic interactions alone (Tolls, 2001). Such interactions could be particularly important in drinking water treatment, where mineral oxides provide a relatively high density of surface functional groups that could interact with polar pharmaceuticals. For example, approximately $25 \%$ of the NPEs in groundwater were removed during coagulation with alum (Fielding et al., 1998). Therefore, it is possible that some polar EDCs or PPCPs could be removed during coagulation.

Despite the predictions, available data from pilot and full-scale water treatment plants indicate that removal will be modest at best. Neither lime softening nor alum coagulation (conventional or enhanced dosages ranging from 6 to $18 \mathrm{mg} / \mathrm{L}$ ) demonstrated atrazine removal (Zhang and Emary, 1999). Coagulation/flocculation/sedimentation with alum and iron salts or excess lime/soda ash softening did not result in significant removal of antibiotics (i.e., carbadox, sulfachlorpyridazine, sulfadimethoxine, sulfamerazine, sulfamethazine, sulfathiazole, and trimethoprim) (Adams et al., 2002). In another study, ferric chloride precipitation did not remove several pharmaceuticals frequently detected in surface waters (diclofenac, carbamazepine, bezafibrate, and clofibric acid) (Sacher et al., 2000). Certain pesticides were poorly removed by coagulation and $\sim 50 \%$ of the PAHs pyrene, fluoranthene, and anthracene were removed through hydrophobic interactions (Eldib and Aly, 1977; Rebhun et al., 1998). On the basis of predictions of hydrophobic interactions and results of fullscale measurements, we conclude that EDCs and PPCPs not associated with colloidal or particulate material will most likely be poorly removed during coagulation.

\section{Activated carbon adsorption}

Activated carbon can be used to remove many different pesticides, pharmaceuticals, and estrogenic compounds (Robeck et al., 1965; Steiner and Singley, 1979; Miltner et al, 1989; Pirbazari et al, 1992; Sacher et al., 2000; West, 2000). The performance of activated carbon depends on the properties of the activated carbon sorbent (surface area, pore size distribution, surface charge, oxygen content) and on the properties of the solute (shape, size, charge, and hydrophobicity). Hydrophobic interactions are the dominant mechanism of removal for most organic compounds in activated carbon adsorption systems. However, ion exchange interactions can result in removal of polar solutes (Youssef et al., 1982; Matsumura et al., 1985; Crittenden et al., 1999). As a result of the hydrophobic interactions, activated carbon efficiently removes most nonpolar organic compounds (i.e., those compounds with $\log K_{\mathrm{OW}}>2$ ). The ability of activated carbon to remove more polar compounds will de- 
pend upon the strength of the polar interactions, which are difficult to predict $a$ priori.

NOM in water competes for adsorption sites and decreases the activated carbon capacity for micropollutants (Newcombe et al., 1997a, 1997b; Pendleton et al., 1997; Newcombe, 1999; Wu and Pendleton, 2001). As a result, treatability studies conducted in distilled water should be interpreted with caution because they do not consider competition from NOM. For example, addition of 10 to $20 \mathrm{mg} / \mathrm{L}$ of powdered activated carbon (PAC) to distilled and river water spiked with seven antibiotics achieved between $50 \%$ and greater than $99 \%$ removal. However, when the same experiments were repeated in river water containing $10.7 \mathrm{mg} / \mathrm{L}$ of NOM, removal decreased by 10 to $20 \%$ (Adams et al., 2002).

Although results of full-scale treatment studies with EDCs and PPCPs are not available, considerable information is available on the ability of activated carbon to remove compounds that cause taste and odor problems. PAC is usually added in presedimentation or contact basins prior to coagulation, sedimentation, and filtration. Usually, 1 to $3 \mathrm{~h}$ of contact is provided for the PAC, after which the PAC settles out in the sedimentation tank, and is then disposed with other WTP sludges. For example, PAC added at dosages ranging from 5 to $50 \mathrm{mg} / \mathrm{L}$ removed greater than $90 \%$ of methylisoborneol ( $\mathrm{Log}$ $K_{\mathrm{OW}}=3.1$ ) in raw water (Gillogly et al., 1998; Zhang and Emary, 1999; Bruce et al., 2002). Under the conditions encountered in drinking water treatment plants, removal of micropollutants by PAC tends to be independent of initial contaminant concentrations (Knappe et al., 1998; Leung and Segar, 1999). In a laboratory, $20 \mathrm{mg} / \mathrm{L}$ of PAC with 1-h contact time reduced the concentration of the moderately hydrophobic pesticide lindane ( $\log$ $K_{\mathrm{OW}}=3.72$ ) from 10 to $0.1 \mu \mathrm{g} / \mathrm{L}$ (Kouras et al., 1998). Laboratory studies conducted with EDCs suggest that PAC will be effective at removing between approximately 60 and $80 \%$ of nonylphenol and NPEs (Carlile, et al., 1996; Fielding et al., 1998). Unpublished PAC experiments in distilled water and/or surface water conducted by the authors suggest similar removals of E2, EE2, triclosan, dilantin, bisphenol A, and octylphenol.

Granular activated carbon (GAC) systems operate as adsorptive packed beds or filters. While PAC is added, contacted with water $(\sim 4 \mathrm{~h})$, and removed (settling/filtering), GAC systems operate with stationary phase (GAC packed beds), continuous water flow, and contact times of less than $30 \mathrm{~min}$. GAC systems remain in operation for months to years, and thus achieve pseudo-equilibrium with micropollutants in the influent water (Crittenden et al., 1991). The influent micropollutant and DOC concentrations, contact time with the GAC, and type of GAC impact the adsorption and breakthrough of the micropollutant across GAC systems. For example, the adsorption characteristics of three types of activated carbon for radiolabeled $17 \beta$-estradiol were studied to determine the time necessary to reach equilibrium between the solid and the liquid phase (Fuerhacker et al., 2001). 17 $\beta$ Estradiol was quickly adsorbed and conditions close to equilibrium were reached after 50-180 min. The equilibrium concentrations were calculated to be at $49-81 \%$ of the initial concentrations between 1 and $100 \mathrm{ng} / \mathrm{L}$, with $0.51 \mathrm{ng} / \mathrm{L}$ remaining for a $1 \mathrm{ng} / \mathrm{L}$ initial concentration and between 5.9 and $14.6 \mathrm{ng} / \mathrm{L}$ for a $100 \mathrm{ng} / \mathrm{L}$ initial concentration. Wang and Lee (1997) determined GAC (coal base) design criteria to remove various micropollutants including organophosphorus, volatile organic chemicals, and phenol found in drinking water sources having different background DOC concentrations. It was found that sorption capacities of the micropollutants were reduced with increasing background DOC concentration due presumably to DOC pore blockage of the GAC and reduction of the surface area available for the adsorption of micropollutants. The results obtained from activated carbon filtration for the removal of nonylphenol showed that contact times of 4 days and $24 \mathrm{~h}$ and activated carbon dosages of 0.1 and $1 \mathrm{~g} / \mathrm{L}$ could be obtained with nonylphenol total contaminant loadings up to $0.01 \mathrm{mg} / \mathrm{g}$ on saturation of the GAC (Tanghe and Verstraete, 2001). The influence of temperature $\left(4\right.$ or $28^{\circ} \mathrm{C}$ ) on nonylphenol adsorption on GAC was negligible and the sorption capacity of dissolved humic acids for nonylphenol was considerable at a nonylphenol concentration of $10 \mu \mathrm{g} / \mathrm{L}$.

The use of GAC leads to very high removal of micropollutants during the first weeks/months, but over time, more strongly adsorbable constituents can displace previously adsorbed compounds. The relative strength of adsorption is often characterized by Freundlich isotherm parameters (e.g., sorption capacity, $K$ ). Freundlich " $K$ " values are available for numerous compounds regulated under the Safe Drinking Water Act (Speth and Adams, 1993; Speth and Miltner, 1998), and correlated with physical properties of organic compounds (Crittenden et al., 1999). Freundlich constants can be used to predict PAC and GAC performance (Knappe et al., 1998; Najm et al., 1991a, 1991b). Typically, when $K$ values were greater than 200 the activated carbon process is considered technically and economically feasible. Although $K$ values are not currently available for emerging EDCs and PPCPs, quantitative structure-activity relationship models could be used to estimate the values. Generally, compounds with $\log K_{\text {Ow }}$ values $>2$ have Freundlich $K$ values $>$ 200 and, therefore, many EDCs and PPCPs (Table 1) may be amenable to removal by PAC or GAC. 


\section{Oxidation processes}

In water treatment systems, several of the commonly used disinfectants also can result in transformation of EDCs and PPCPs. In drinking water treatment systems, chlorine, chlorine dioxide, and ozone are frequently used while disinfection of wastewater effluent usually is limited to chlorine. Oxidation of EDCs and PPCPs is selective for certain chemical structures and functional groups. Among the three oxidants, ozone tends to be the most reactive; however, all three oxidants are strong electrophiles that exhibit similar trends of reactivity with organic compounds. As a result, certain generalizations can be observed in the reactivity of the oxidants (Hoigne and Bader, 1983a, 1983b, 1994; Hoigne et al., 1985; Larson and Weber, 1994; Tratnyek and Hoigne, 1994; Gallard and von Gunten, 2002): (1) dissociated acidic compounds are more reactive than protonated forms (i.e., reactivity increases with $\mathrm{pH}$ ), but nondissociated bases are more reactive when not protonated; (2) general order of reactivity from highest to lowest for aromatic or aliphatic compounds: thiols $>$ amines $>$ hydroxyl $>$ carboxyl; and (3) aromatic compounds are more reactive than aliphatic compounds.

Chlorination. In the United States, free chlorine (i.e., $\mathrm{HOCl}$ and $\mathrm{OCl}^{-}$) is commonly used for disinfection and oxidation of reduced inorganic species such as $\mathrm{Fe}(\mathrm{II})$, $\mathrm{Mn}(\mathrm{II})$, and S(-II). In the presence of ammonia, free chlorine will produce chloramines, which tend to be less reactive than free chlorine (Weil and Morris, 1974). For example, the application of free chlorine resulted in the removal of $>95 \%$ of the herbicide glyphosate in Ohio River water after 15 min while monochloramine did not remove any of the herbicide under similar conditions (Speth, 1993). The reduced reactivity of chloramine is particularly important in wastewater treatment plants because enough ammonia will be present to convert free chlorine into monochloramine in wastewater effluent that has not undergone nitrification.

Free chlorine reacts rapidly with phenolic compounds, mainly through the reaction between hypochlorous acid and the deprotonated phenolate anion (Faust and Hunter, 1967). The reaction results in sequential chlorine addition to the aromatic ring followed by ring cleavage. The reactivity of the phenolic functional group likely explains the transformation of estrogenic hormones and nonylphenol by chlorine observed in laboratory studies (West, 2000). However, these results conflict with findings in Japan that report chlorine as ineffective for the degradation of estrogens (Matsui and Takigami, 2000).

The transformation of several amine-containing antibiotics (Adams and Kuzhikannil, 2000; Huang et al.,
2001), diclofenac (Sedlak and Pinkston, 2001), and caffeine (Gould and Richards, 1984), was observed in laboratory experiments with chlorine. Additional studies are needed to assess the reactivity of compounds with other potentially reactive functional groups and the relative importance of these reactions under conditions used for disinfection of water and wastewater. In addition, the reactions between chlorine and EDCs and PPCPs necessitate quenching of chlorine in samples that may have a chlorine residual, especially when 24-h composite samples are collected. For example, chlorination $(1 \mathrm{mg} / \mathrm{L} ; \mathrm{pH}=$ 7.5) removed $>90 \%$ of seven amine-substituted antibiotics from river water within $40 \mathrm{~min}$ (Adams and Kuzhikannil, 2000). Therefore, careful attention must be directed at discerning removal by chlorine vs. removal from a quenching agent.

Chlorine dioxide. Chlorine dioxide $\left(\mathrm{ClO}_{2}\right)$ can oxidize herbicides, pesticides, and PAHs, and is generally a stronger and faster oxidant than free chlorine (Ravacha and Blits, 1985). Chlorine dioxide application (1-1.5 $\mathrm{mg} / \mathrm{L}$ for $10 \mathrm{~min}$ ) at two full-scale WTPs removed less than $30 \%$ of the total pesticide concentration $(0.05$ to 3.5 $\mu \mathrm{g} / \mathrm{L}$ ) in the raw water (Griffini et al., 1999). $\mathrm{ClO}_{2}$ was more effective than free chlorine at oxidizing amine-containing pesticides (phenylamide) and herbicides (ametryn) than for other herbicides (isoproturon, glyphosate) (Eldib and Aly, 1977; Speth, 1993; Lopez et al., 1997). Chlorine dioxide $(2 \mathrm{mg} / \mathrm{L}$ at $\mathrm{pH} 7$ ) removed $50 \%$ of several PAHs, but contact times required for this level of oxidation ranged between $6 \mathrm{~s}$ (benzo[a]pyrene) to $17 \mathrm{~h}$ (benzo[b]fluranthene) for different PAHs (Ravacha and Blits, 1985). No additional information is available on oxidation of EDCs or PPCPs by $\mathrm{ClO}_{2}$. However, we anticipate that $\mathrm{ClO}_{2}$ will react with compounds containing phenolic amino and thiol functional groups (Hoigne and Bader, 1994).

Ozonation. Ozone $\left(\mathrm{O}_{3}\right)$ is used in water treatment as both a disinfectant and an oxidant. During ozonation, two strong oxidants can lead to transformation of EDCs and PPCPs and other organic compounds: molecular $\mathrm{O}_{3}$ and hydroxyl radicals (HO*) (Hoigne and Bader, 1983a, 1983b). $\mathrm{O}_{3}$ is a selective electrophile that reacts with amines, phenols, and double bonds in aliphatic compounds, while $\mathrm{HO}^{\bullet}$ reacts less selectively with secondorder rate constants $\left(k_{\mathrm{HO}}\right)$ on the order of $10^{8}$ to $10^{10}$ $\mathrm{M}^{-1} \mathrm{~S}^{-1}$ (Buxton et al., 1988; Haag and Yao, 1992). As a result of the selective nature of ozone, transformation of micropollutants may require the use of advanced oxidation processes (AOPs), such as UV/hydrogen peroxide $\left(\mathrm{H}_{2} \mathrm{O}_{2}\right), \mathrm{O}_{3} / \mathrm{H}_{2} \mathrm{O}_{2}$, or UV/O 3 (Hoigne, 1998; Acero et al., 
2000; Acero and Von Gunten, 2001). Given information on water quality (e.g., alkalinity, $\mathrm{pH}$, and NOM) it may be possible to estimate the concentrations of $\mathrm{O}_{3}$ and $\mathrm{OH}$ present during ozone treatment. Such data can be used with second-order rate constants to predict the rate of transformation of EDCs and PPCPs during ozone treatment.

Preliminary data for a set of EDC/PPCP compounds indicate a wide range of reactivity for reactions with ozone; roxithromycin $\left(4.5 \times 10^{6} \mathrm{M}^{-1} \mathrm{~s}^{-1}\right)$, diclofenac $\left(>10^{5}\right.$ $\left.\mathrm{M}^{-1} \mathrm{~s}^{-1}\right)$, ethynylestradiol $\left.>10^{5} \quad \mathrm{M}^{-1} \mathrm{~s}^{-1}\right)$, carbamazepene $\left(0.78-3 \times 10^{5} \mathrm{M}^{-1} \mathrm{~s}^{-1}\right)$, sulfamethoxazole $\left(10^{5} \mathrm{M}^{-1} \mathrm{~s}^{-1}\right)$, bezafibrate $\left(590 \mathrm{M}^{-1} \mathrm{~s}^{-1}\right)$, ibuprofen (6 $\left.\mathrm{M}^{-1} \mathrm{~s}^{-1}\right)$, diazepam $\left(0.95 \mathrm{M}^{-1} \mathrm{~s}^{-1}\right)$, and iopramide $(<0.8$ $\mathrm{M}^{-1} \mathrm{~s}^{-1}$ ) (Huber et al., 2002). Most $k_{\mathrm{HO}}$ second-order rate constant values were on the order of $5 \times 10^{9} \mathrm{M}^{-1} \mathrm{~s}^{-1}$. Under conditions encountered in water treatment systems $\left(\left[\mathrm{HO}^{\circ}\right] /\left[\mathrm{O}_{3}\right] \approx 10^{-8}\right)$, only those compounds with ozone rate constants $\left(k_{\mathrm{O} 3}\right)$ greater than $\sim 50 \mathrm{M}^{-1} \mathrm{~s}^{-1}$ will be transformed to an appreciable degree $(>50 \%)$ through direct reactions with ozone. Therefore, during ozonation the mechanism of oxidation will be $\mathrm{O}_{3}$ or a combination of $\mathrm{O}_{3}$ and $\mathrm{HO}^{\circ}$. Some reports have documented the removal of EDCs and PPCPs in bench-scale treatment systems. For example, ozonation removed diclofenac, carbamazepine, and bezafibrate, but not clofibric acid (Sacher et al., 2000). Improved removal of clofibric acid, ibuprofen, and diclofenac occurred when ozonation was conducted in the presence of hydrogen peroxide ( 0.4 to $0.7 \mathrm{mg} \mathrm{H}_{2} \mathrm{O}_{2} / \mathrm{mg}$ ozone dosed) (Carlson et al., 2000). Estrogen steroids and nonylphenols also reacted with ozone under conditions comparable to those encountered in water treatment systems (West, 2000). Ozonation of estrogenic chemicals in spiked groundwater indicated some removal of mestranol, estradiol, ethynylestradiol, norethistrone, ethistrone, and estriol by aeration alone, and higher removals with applied ozone (Carlile et al., 1996). However, most EDCs and PPCPs have low Henry's Law constants, and aeration would not appear to be an effective means for removal. In separate work, a linear relationship between ozone dose and fraction of $\mathrm{E} 2$ remaining in model waters was apparently observed during $\mathrm{O}_{3}$ and $\mathrm{O}_{3} / \mathrm{H}_{2} \mathrm{O}_{2}$ processes (Kosaka et al., 2000).

Ultraviolet $(U V)$ irradiation. UV lamps are used widely for microbial disinfection of water and wastewater. In several cases, they also have been used for treatment of micropollutants (Mofidi et al., 2000). Because several EDCs and PPCPs have chromophores that lead to adsorption of light at UV wavelengths, many may be amenable to transformation during UV treatment. However, typical UV doses required for disinfection (i.e., $<5$ to $30 \mathrm{~mJ} / \mathrm{cm}^{2}$ ) are several orders of magnitude lower than those used for treatment of micropollutants. Therefore, UV treatment of EDCs and PPCPs probably will not be economically competitive with other advanced treatment methods (e.g., reverse osmosis). As discussed previously, UV treatment in combination with ozone or hydrogen peroxide may be practical in some situations.

UV alone or as part of AOP systems has been used to oxidize pesticides and other micropollutants, primarily in groundwater (Beltran et al., 1992, 1993, 1996, 2000; Larson and Weber, 1994; Chiron et al., 2000; De Laat et al., 1999). Few reports of EDC or PPCP removal during UV treatment exist. For example, oxidation of fragrances (nitromusks) is achieved using UV light produced by lowpressure mercury lamps with faster transformation rates with the addition of hydrogen peroxide (Neamtu et al., 2000). At UV doses of $3000 \mathrm{~mJ} / \mathrm{cm}^{2}$, the removal of different antibiotics from distilled and natural waters ranged between 50 to $80 \%$ for the seven antibiotics, which were all selected because the compounds were detectable by HPLC.

\section{Biotransformation}

Biotransformation may provide a basis for the cost-effective removal of EDCs and PPCPs from water. Available data from municipal wastewater treatment systems suggest that many of the compounds are transformed by bacteria (Johnson et al., 2000; Johnson and Sumpter, 2001; Ternes et al., 1999a, 1999b). However, little is known about the importance of biotransformation in drinking water treatment plants or in soil. Data from sites where wastewater effluent is used to recharge aquifers (i.e., soil aquifer treatment systems) indicate that many of the PPCPs are removed during the first few weeks of passage through the aquifer (Drewes et al., 2001b). However, certain recalcitrant compounds including the antiepileptics, carbamazepine and primidone, and iodinated X-ray contrast media persist during infiltration through vadose and saturated soil zones (Drewes et al., 2001a, 2001b). Similar results were observed in bank filtration (Heberer, 2002) and during slow sand filtration in drinking water treatment plants (Sacher et al., 2000). These studies confirm that some PPCPs are biodegradable, while others are not or have not yet been investigated.

\section{Membrane separation}

Most organic EDC/PPCP compounds range from 150 to 500 Daltons in molecular size. As a result, only those compounds associated with particles or colloidal organic matter will be removed during microfiltration and ultrafiltration (UF). For example, microfiltration ( 0.1 to 0.4 $\mu \mathrm{m})$ did not remove two steroid hormones and six dif- 
ferent acidic drugs and beta blockers at two different fullscale water recycling systems treating tertiary municipal wastewater effluent (Huang and Sedlak, 2001). Most EDCs and PPCPs will be removed by reverse osmosis (RO) and tight nanofiltration (NF) systems (i.e., those with a low molecular weight cutoff). For example, RO can achieve greater than $90 \%$ removal of steroid hormones (Huang and Sedlak, 2001).

Experience with other organic/inorganic compounds suggests that polar compounds and charged compounds that interact with membrane surfaces will be better removed than less polar or neutral compounds (Huxstep and Sorg, 1988; Duranceau et al., 1992; Berg et al., 1997; Carlson, 2000; Yoon et al., 2001, 2002a, 2002b). For example, the removal efficiency of several low molecular weight compounds ( $\sim 150$ Daltons) increased at higher $\mathrm{pH}$ due to electrostatic repulsion between $\mathrm{RO}$ membrane and dissociated organic compounds (Ozaki and Li, 2002). In the same work, removal of neutral organic compounds increased linearly with molecular weight and molecular width. Hydrophobicity of the micropollutant and membrane also affect removal. For example, pesticide adsorption on, and removal by, RO and NF membranes was correlated with Log $K_{\mathrm{OW}}$ (Kiso et al., 2001a, 2001b).

Several recent laboratory studies also have demonstrated the removal of PPCPs from water. Compounds removed by RO included several different antibiotics (Adams et al., 2002). Results from laboratory studies conducted by adding compounds to deionized water should be interpreted with caution because the presence of cations and NOM can alter removal efficiency. RO, NF, and charged UF membranes can remove inorganic EDCs (e.g., arsenic, perchlorate) (Uludag et al., 1997; Urase et al., 1997; Chianese et al., 1999; Vrijenhoek and Waypa 2000; Van der Bruggen et al., 2001; Yoon et al., 2002a). Overall, membrane separation provides an excellent barrier for most EDCs and PPCPs, except the lower molecular weight uncharged compounds.

\section{SUMMARY OF WATER TREATMENT PROCESSES FOR EDC AND PPCP CONTROL}

Table 2 provides a generalized summary of the potential for removal of various classes of EDCs and PPCPs. Estimates of removal are based upon chemical structure (size, hydrophobicity, functional group composition).

1. Coagulation would only be expected to remove hydrophobic compounds associated with particular or colloidal material with high organic carbon content.

2. Activated carbon adsorption removes hydrophobic compounds very well, but competition between more polar or larger molecular weight compounds and other matrix organics has not been well documented.

3. Oxidation will preferentially attack compounds with electron-activating functional groups (thiols, amines, hydroxyl) located near $\mathrm{C}=\mathrm{C}$ bonds (benzene rings). Organic compounds will react more rapidly with ozone than chlorine dioxide or chlorine.

4. Membranes provide a physical barrier capable of high removals, but removals are dependent upon compound structure (size, polarity) and membrane properties.

Given experience with removing pesticides and other trace micropollutants, water treatment technologies can be integrated into existing WTPs or designed into new facilities to assure high levels of EDC and PPCP compound removal. For example, simple process modifications such as addition of powder-activated carbon to a convention WTP during periods of high-risk of EDC or PPCP in the raw water (e.g., low streamflow during the summer comprised primarily of upstream wastewater discharge) could provide high levels of removal. Incorporation of more advanced technologies could require extensive modifications to WTP operations. For example, inclusion of $\mathrm{O}_{3}$ or AOP systems should be followed by biofiltration to remove polar oxidation byproducts. Combinations of treatments may be required to remove mixtures of compounds that may occur in a raw drinking water (e.g., membranes, oxidation).

\section{Future research needs}

A great deal of additional data are needed to understand the relevance of trace EDCs and PPCPs in water and how these compounds may be removed by water treatment. It is important to gain more information as to the toxicological impacts of trace levels of EDCs and PPCPs in water. Once these impacts are quantified, safe exposure limits can be established that will allow the water industry to determine "good removal" rates. Standardized analytical methods for detection of commonly occurring EDCs and PPCPs are critical. These methods should be based on equipment that most laboratories could afford and have expertise to operate. Once analytical methodologies are available, environmental screening should include testing for bioaccumulation of EDCs in wildlife and humans. Future studies should seek to identify population-levelimpacts of EDCs and PPCPs on wildlife and relate these effects to biomarkers.

Although reports of EDC and PPCP removal by water treatment are beginning to become available, much is still unknown as to the fate of these emerging contaminants in WTPs. It is critical to understand the size dis- 
tribution of EDCs and PPCPs and their association with particulate and colloidal materials in raw drinking water supplies to assess removal across conventional WTPs designed for particular and colloidal removal. The oxidation capability of chloramines on EDC/PPCP compounds reactive with chlorine should be quantified. Oxidation byproducts should be identified and tested for both endocrine and carcinogenic health risks. Effects of nonionic polymers on improving EDC/PPCP removal during coagulation have not been reported. Aerobic biofilms should be compared to nonbiological sand filters to quantify the potential benefits of changing the point of chlorination in a conventional WTP to optimize EDC/PPCP removal. Breakthrough curves should be generated for GAC packed columns with a variety of EDC and PPCP compounds in water containing NOM to evaluate potential displacement/desorption of organics over time. Partition and permeation coefficients across membranes for EDCs and PPCPs should be determined. Additionally, membranes should be evaluated for leaching of plasticizers that may act as EDCs. Integrated water management options, which include source water protection, should complement advanced drinking water treatment.

\section{ACKNOWLEDGMENTS}

Funding for this review was provided in part by the American Water Works Association Research Foundation (AWWARF) project 2758 entitled "Evaluation of Conventional and Advanced Treatment Processes to Remove Endocrine Disruptors and Pharmaceutically Active Compounds."

\section{REFERENCES}

ACERO, J.L., STEMMLER, K., and VON GUNTEN, U. (2000). Degradation kinetics of atrazine and its degradation products with ozone and $\mathrm{OH}$ radicals: A predictive tool for drinking water treatment. Environ. Sci. Technol. 34, 591-597.

ACERO, J.L., and VON GUNTEN, U. (2001). Characterization of oxidation processes: Ozonation and the AOP O3/H2O2. J. Am. Water Works Assoc. 93, 90-100.

ADAMS, C., WANG, Y., LOFTIN, K., and MEYER, M. (2002). Removal of antibiotics from surface and distilled water in conventional water treatment processes. J. Environ. Eng. 128, 253-260.

ADAMS, C.D., and KUZHIKANNIL, J.J. (2000). Effects of $\mathrm{UV} / \mathrm{H} 2 \mathrm{O} 2$ peroxidation on the aerobic biodegradability of quaternary amine surfactants. Water Res. 34, 668-672.

ADAMS, N.R. (1998). Natural and anthropogenic environ- mental estrogens: The scientific basis for risk assessment. Clover phyto-estrogens in sheep in Western Australia. Pure Appl. Chem. 70, 1855-1862.

AHEL, M., MCEVOY, J., and GIGER, W. (1993). Bioaccumulation of the lipophilic metabolites of nonionic surfactants in freshwater organisms. Environ. Pollut. 79, 243-248.

AHERNE, G.W., ENGLISH, J., and MARKS, V. (1985). The role of immunoassay in the analysis of microcontaminants in water samples. Ecotoxicol. Environ. Saf. 9, 79-83.

AHLBORG, U.G., LIPWORTH, L., TITUS-ERNUSTOFF, L., HSIEH, C.-C., HANBERG, A., BARON, J., TRICHOPOULOS, D., and ADAMI, H.O. (1995). Organochlorine compounds in relation to breast cancer, endometrial cancer, and endometriosis: An assessment of the biological and epidemiological evidence. Crit. Rev. Toxicol. 25, 463-531.

ANDERSON, M.J., MILLER, M.R., and HINTON, D.E. (1996). In vitro modulation of 17-b estradiol-induced vitellogenin synthesis: Effects of cytochrome P4501A1 inducing compounds on rainbow trout (Onchorhynchus mykiss) liver cells. Aquat. Toxicol. 34, 327-350.

ARCAND-HOY, L.D., NIMROD, A.C., and BENSON, W.H. (1998). Endocrine-modulating substances in the environment: Estrogenic effects of pharmaceutical products. Int. J. Toxicol. 17, 139-158.

ASHBY, J. (1997). A hierarchical approach to the evaluation of chemicals for estrogenic and other endocrine-disrupting properties. Environ. Toxicol. Pharmacol. 3, 87-90.

BELTRAN, F.J., GARCIA-ARAYA, J.F., RIVAS, J., ALVAREZ, P.M., and RODRIGUEZ, E. (2000). Kinetics of simazine advanced oxidation in water. J. Environ. Sci. Health Part B-Pesticides Food Contam. Agric. Waste 35, 439-454.

BELTRAN, F.J., GOMEZSERRANO, V., and DURAN, A. (1992). Degradation kinetics of para-nitrophenol ozonation in water. Water Res. 26, 9-17.

BELTRAN, F.J., GONZALEZ, M., RIVAS, F.J., and ALVAREZ, P. (1996). Aqueous UV radiation and UV/H2O2 oxidation of atrazine first degradation products: Deethylatrazine and deisopropylatrazine. Environ. Toxicol. Chem. 15, 868-872.

BELTRAN, F.J., OVEJERO, G., and ACEDO, B. (1993). Oxidation of atrazine in water by ultraviolet-radiation combined with hydrogen-peroxide. Water Res. 27, 1013-1021.

BERG, P., HAGMEYER, G., and GIMBEL, R.P. (1997). Removal of pesticides and other micropollutants by nanofiltration. Desalination 113, 205-208.

BEVANS, H.E., GOODBRED, S.L., MIESNER, J.F., WATKINS, S.A., GROSS, T.S., DENSLOW, N.D., and SCHOEB, T. (1996). Synthetic organic compounds and carp endocrinology and histology in Las Vegas Wash and Las Vegas and Callville Bays of Lake Mead, Nevada, 1992 and 1995. Water-Resource Investigat. Rep. 96-4266.

BITMAN, J., and CECIL, H.C. (1970). Estrogenic activity of 
DDT analogs and polychlorinated biphenyls. J. Agricul. Food Chem., 18, 1108-1112.

BITMAN, J., CECIL, H.C., HARRIS, S.J., and FRIES, G.F. (1968). Estrogenic activity of o, $\mathrm{p}^{\prime}$-DDT in the mammalian uterus and avian oviduct. Science 162, 371-372.

BORTONE, S.A., and CODY, R.P. (1999). Morphological masculinization in poeciliid females from a paper mill effluent receiving tributary of the St. Johns River, Florida, USA. Bull. Environ. Contam. Toxicol. 63, 150-156.

BROOKBANKS, E.O., WELCH, R.A.H., and COUP, M.R. (1969). Estrogens in pasture and a possible relation with mastitis. NZ Vet. J. 17, 159-160.

BRUCE, D., WESTERHOFF, P., and BRAWLEYCHESWORTH, A. (2002). Removal of 2-methylisoborneol and geosmin in surface water treatment plants in Arizona. $J$. Water Supp. Res. Technol. AQUA. 51, 183-198.

BUXTON, G.V., GREENSTOCK, C.L., HELMAN, W.P., and ROSS, A.B. (1988). Critical review of rate constants for reactions of hydrated electrons, hydrogen atoms and hydroxyl radicals $(\times \mathrm{OH} / \times \mathrm{O}-)$ in aqueous solution. J. Phys. Ref. Data, 17, 513-851.

CARLILE, P., FIELDING, M., HARDING, L., HART, J., HUTCHISON, J., and KANDA, R. (1996). Effect of water treatment processes on oestrogenic chemicals. UK WIR Report 96/DW/05/01.

CARLSEN, E., GIWERCMAN, A., KEIDING, N., and SKAKKEBAEK, N.E. (1995). Declining sperm quality and increasing incidence of testicular cancer: Is there a common cause? Environ. Health Perspect. 130, 137-139.

CARLSON, M., SANCHEZ, D., and MUYLWYK, Q. (2000). Treatment for endocrine cisruptors. AWWA 2000 Annual Conference, Sunday Workshop, Denver, CO.

CASTILLO, M., and BARCELO, D. (1999). Identification of polar toxicants in industrial wastewaters using toxicity-based fractionation with liquid chromatography/mass spectrometry. Anal. Chem. 71, 3769-3776.

CHIANESE, A., RANAURO, R., and VERDONE, N. (1999). Treatment of landfill leachate by reverse osmosis. Water Res. 33, 647-652.

CHIOU, C.T., MCGRODDY, S.E., and KILE, D.E. (1998). Partition characteristics of polycyclic aromatic hydrocarbons on soils and sediments. Environ. Sci. Technol. 32, 264-269.

CHIRON, S., FERNANDEZ-ALBA, A., RODRIGUEZ, A., and GARCIA-CALVO, E. (2000). Pesticide chemical oxidation: State-of-the-art. Water Res. 34, 366-377.

COLBORN, T., DUMANOSKI, D., and MYERS, J.P. (1997). Our Stolen Future. New York: Plume Publishing.

COOK, J.W., DODDS, E.C., HEWETT, C.L., and LAWSON, W. (1934). Estrogenic activity of some condensed ring compounds in relation to their other biological activities. Proceed. R. Soc. Lond. B114, 272-286.
CRITTENDEN, J.C., REDDY, P.S., ARORA, H., TRYNOSKI, J.H., PERRAM, D.L., and SUMMERS, R.S. (1991). Predicting gas performance with rapid small-scale column tests. J. Am. Water Works Assoc. 83, 77-87.

CRITTENDEN, J.C., SANONGRAJ, S., BULLOCH, J.L., HAND, D.W., ROGERS, T.N., SPETH, T.F., and ULMER, M. (1999). Correlation of aqueous-phase adsorption isotherms. Environ. Sci. Technol. 33, 2926-2933.

DAUGHTON, C.G., and TERNES, T.A. (1999). Pharmaceuticals and personal care products in the environment: Agents of subtle change? Environ. Health Perspect. 107, 907-938.

DE LAAT, J., GALLARD, H., ANCELIN, S., and LEGUBE, B. (1999). Comparative study of the oxidation of atrazien and acetone by $\mathrm{H} 2 \mathrm{O} 2 / \mathrm{UV}, \mathrm{Fe}(\mathrm{III}) / \mathrm{UV}, \mathrm{Fe}(\mathrm{III}) / \mathrm{H} 2 \mathrm{O} 2 / \mathrm{UV}$ and $\mathrm{Fe}(\mathrm{II})$ or $\mathrm{Fe}(\mathrm{III}) / \mathrm{H} 2 \mathrm{O} 2$. Chemosphere 39, 2693-2706.

DESBROW, C., ROUTLEDGE, E.J., BRIGHTY, G.C., SUMPTER, J.P., and WALDOCK, M. (1998). Identification of estrogenic chemicals in STW effluent. 1. Chemical fractionation and in vitro biological screening. Environ. Sci. Technol. 32, 1549-1558.

DREWES, J., HEBERER, T., and REDDERSEN, K. (2001). Removal of pharmaceuticals during conventional wastewater treatment, advanced membrane treatment and soil-aquifer treatment. 2nd International Conference on Pharmaceuticals and Endocrine Disrupting Chemicals in Water, Minneapolis, MN.

DREWES, J.E., FOX, P., and JEKEL, M. (2001b). Occurrence of iodinated X-ray contrast media in domestic effluents and their fate during indirect potable reuse. J. Environ. Sci. Health Part a-Toxic/Hazard Subs. Environ.l Eng. 36, 1633-1645.

DURANCEAU, S.J., TAYLOR, J.S., and MULFORD, L.A. (1992). Soc removal in a membrane softening process. J. Am. Water Works Assoc. 84, 68-78.

ELDIB, M.A., and ALY, O.A. (1977). Removal of phenylamide pesticides from drinking waters. 1. Effect of chemical coagulation and oxidants. Water Res. 11, 611-616.

EPA. (1997). Special report on environmental endocrine disruption: An effects assessment and analysis. Washington, DC: Office of Research and Development. EPA/630/R96/012.

EPA. (1998). Endocrine disruptor screening and testing advisory committee (EDSTAC) final report. Environmental Protection Agency.

FAUST, S.D., and HUNTER, J.V. (1967). Principles and applications of water chemistry. New York: John Wiley and Sons.

FAWELL, J.K., SHEAHAN, D., JAMES, H.A., HURST, M., and SCOTT, S. (2001). Oestrogens and oestrogenic activity in raw and treated Severn Trent water. Water Res. 35, $1240-1244$.

FDA. (1998). Guidance for industry environmental assessment of human drug and biologics applications. Food and Drug Administration Report, USA. 
FIELDING, M., HARDING, L., JAMES, C., and MOLE, N. (1998). Removal of nonylphenol ethoxylates by water treatment processes. UK WIR Report 98/TX/01/5.

FISHER, A.L., KEASLING, H.H., and SCHUELER, F.W. (1952). Estrogenic action of some DDT analogs. Proc. Soc. Exp. Biol. Med. 81, 439-441.

FOLMAR, L.C., DENSLOW, N.D., RAO, V., CHOW, M., CRAIN, D.A., ENBLOM, J., MARCINO, J., and GUILLETTE L.J., JR. (1996). Vitellogenin induction and reduced serum testosterone concentrations in feral male carp (Cyprinus carpio) captured near a major metropolitan sewage treatment plant. Environ. Health Perspect. 104, 1096-1101.

FRY, D.M., and TOONE, C.K. (1981). DDT-induced feminization of gull embryos. Science 231, 919-924.

FRY, D.M., TOONE, C.K., SPEICH, S.M., and PEARD, R.J. (1987). Sex ratio skew and breeding patterns of gulls: Demographic and toxicological considerations. Stud. Avian Biol. 10, 26-43.

FUERHACKER, M., DÜRAUER, A., and JUNGBAUER, A. (2001). Adsorption isotherms on $17 \beta$-estradiol on granular activated carbon (GAC). Chemosphere 44, 1573-1579.

GALLARD, H., and VON GUNTEN, U. (2002). Chlorination of phenols: Kinetics and formation of chloroform. Environ. Sci. Technol. 36, 884-890.

GARRISON, A.W., POPE, J.D., and ALLEN, F.R. (1975). GC/MS analysis of organic compounds in domestic wastewaters. Chem. Congr. North Am. Cont., pp. 517-556.

GIBBS, P.E., BRYAN, G.W., and PASCOE, P.L. (1991). TBTinduced imposex in the dogwhelk, Nucella lapillus: Geographical uniformity of the response and effects. Marine Environ. Res. 32, 79-87.

GIESY, J.P., PIERENS, S.L., SNYDER, E.M., MILESRICHARDSON, S., KRAMER, V.J., SNYDER, S.A., NICHOLS, K.M., and VILLENEUVE, D.A. (2000). Effects of 4-nonylphenol on fecundity and biomarkers of estrogenicity in fathead minnows (Pimephales promelas). Environ. Toxicol. Chem. 19, 1368-1377.

GILL, W.B., SCHUMACHER, F.B., BIBBO, M., STRAUS, F.H., and SCHOENBERG, H.W. (1979). Association of diethylstilbestrol exposure in utero with cryptorchidism, testicular hypoplasia and semen abnormalities. J. Urol. 122 , 36-39.

GILLESBY, B.E., and ZACHAREWSKI, T.R. (1998). Exoestrogens: mechanisms of action and strategies for identification and assessment. Environ. Toxicol. Chem. 17, 3-14.

GILLOGLY, T.E.T., SNOEYINK, V.L., ELARDE, J.R., WILSON, C.M., and ROYAL, E.P. (1998). C-14-MIB adsorption on PAC in natural water. J. Am. Water Works Assoc. 90, 98-108.

GOULD, J.P., and RICHARDS, J.T. (1984). The kinetics and products of the chlorination of caffeine in aqueous-solution Water Res. 18, 1001-1009.

GRIFFINI, O., BAO, M.L., BURRINI, D., SANTIANNI, D., BARBIERI, C., and PANTANI, F. (1999). Removal of pesticides during the drinking water treatment process at Florence water supply, Italy. J. Water Serv. Res. Technol.-Aquat. 48, 177-185.

GUILLETTE, L.J. JR., GROSS, T.S., MASSON, G.R., MATTER, N.M., PERCIVAL, H.F., and WOODWARD, A.R. (1994). Developmental abnormalities of the gonad and sex hormone concentrations in juvenile alligators from contaminated and control lakes in Florida. Environ. Health Pespect. 104, 680-688.

GUILLETTE, L.J. JR., PICKFORD, D.B., CRAIN, D.A., ROONEY, A.A., and PERCIVAL, H.F. (1996). Reduction in penis size and plasma testosterone concentrations in juvenile alligators living in a contaminated environment. Gener. Comp. Endocrinol. 101, 32-42.

HAAG, W.R., and YAO, C.C.D. (1992). Rate constants for reaction of hydroxyl radicals with several drinking-water contaminants. Environ. Sci. Technol. 26, 1005-1013.

HALLING, SORENSEN, B., NIELSEN, S.N., LANZKY, P.F., INGERSLEV, F., LUTZHOFT, H.C.H., and JORGENSEN, S.E. (1998). Occurrence, fate and effects of pharmaceutical substances in the environment-A review. Chemosphere 36, 357-393.

HARRIES, J.E., SHEAHAN, D.A., JOBLING, S., MATTHIESSEN, P., NEALL, P., ROUTLEDGE, E.J., RYCROFT, R., SUMPTER, J.P., TYLOR, T., and ZAMAN, N. (1996). A survey of estrogenic activity in United Kingdom inland waters. Environ. Toxicol. Chem. 15, 1993-2002.

HAYES, T.B., COLlinS, A., LEE, M., MENDOZA, M., NORIEGA, N., STUART, A.A., and VONK, A. (2002). Hermaphroditic, demasculinized frogs after exposure to the herbicide atrazine at low ecologically relevant doses. Proc. Natl. Acad. Sci. USA 99, 5476-5480.

HEBERER, T. (2002). Occurrence, fate, and removal of pharmaceutical residues in the aquatic environment: A review of recent research data. Toxicol. Lett. 131, 5-17.

HEBERER, T., and DUMNBIER, U. (2000). Polar DDT metabolites as contaminants of surface, ground and drinking water in Berlin. Nat. Groundwater Assoc.-Emer. Issues Conf., Minneapolis, MN, p. 56.

HENDERSON, A.K., MOLL, D.M., FRICK, E.A., and ZAUGG, S.D. (2001) Presence of wastewater tracers and endocrine disrupting chemicals in treated wastewater effluent and in municipal drinking water. Nat. Groundwater Assoc., Atlanta, GA.

HERBST, A.L., ULFELDER, H., and POSKANZER, D.C. (1971). Adenocarcinoma of the vagina. Association of maternal stilbesterol therapy with tumor appearance in young women. N. Engl. J. Med. 284, 878-881. 
HIGNITE, C., and AZARNOFF, D.L. (1977). Drugs and drug metabolites as environmental contaminants: Chlorophenoxyisobutyrate and salicyclic acid in sewage water effluent. Life Sci. 20, 337-341.

HOIGNE, J. (1998). Chemistry of aqueous ozone and transformation of pollutants by ozonation and advanced oxidation processes. In J. Hrubec, Ed. Handbook of Environmental Chemistry, Heidelberg: Springer-Verlag, pp. 83-141.

HOIGNE, J., and BADER, H. (1983a). Rate constants of reactions of ozone with organic and inorganic-compounds in water. 1. Non-dissociating organic-compounds Water Res. 17, $173-183$.

HOIGNE, J., and BADER, H. (1983b). Rate constants of reactions of ozone with organic and inorganic-compounds in water. 2. Dissociating organic-compounds. Water Res. 17, 185-194.

HOIGNE, J., and BADER, H. (1994). Kinetics of reactions of chlorine dioxide $\left(\mathrm{OCl}_{2}\right)$ in water. 1. Rate constants for inorganic and organic-compounds. Water Res. 28, 45-55.

HOIGNE, J., BADER, H., HAAG, W.R., and STAEHELIN, J. (1985). Rate constants of reactions of ozone with organic and inorganic-compounds in water. 3. Inorganic-compounds and radicals. Water Res. 19, 993-1004.

HUANG, C.H., RENEW, J.E., SMEBY, K.L., PINKSTON, K., and SEDLAK, D.L. (2001). Assessment of potential antibiotic contaminants in water and preliminary occurrence analysis. Water Res. 120, 30-40.

HUANG, C.-H., and SEDLAK, D.L. (2001). Analysis of estrogenic hormones in municipal wastewater effluent and surface water using enzyme-linked immunosorbent assay and gas chromatographytandem mass spectrometry. Environ. Toxicol. Chem. 20, 133-139.

HUBER, M., CANONICA, S., and VON GUNTEN, U. (2002). Oxidative treatment of pharmaceuticals in drinking waters. AWWA EDC Workshop, Cincinnati, OH.

HUXSTEP, M.R., and SORG, T.J. (1988). Reverse osmosis treatment to remove inorganic contaminants from drinking water. EPA-600/S 2-87/109, USEPA.

JENKINS, R., ANGUS, R.A., MCNATT, H., HOWELL, W.M., KEMPPAINEN, J.A., KIRK, M., and WILSON, E.M. (2001). Identification of androstenedione in a river containing paper mill effluent. Environ. Toxicol. Chem. 20, 1325-1331.

JOBLING, S., NOYLAN, M., TYLER, C.R., BRIGHTY, G., and SUMPTER, J.P. (1998). Widespread sexual disruption in wild fish. Environ. Sci. Technol. 32, 2498-2506.

JOHNSON, A.C., BELFROID, A.C., and DI CORCIA, A. (2000). Estimating steroid oestrogen inputs into activated sludge treatment works and observations on their removal from the effluent. Sci. Total Environ. 256, 163-173.

JOHNSON, A.C., and SUMPTER, J.P. (2001). Removal of en- docrine-disrupting chemicals in activated sludge treatment works. Environ. Sci. Technol. 35, 4697-4703.

JOHNSON, A.C., WHITE, C., BESIEN, T.J., and JURGENS, M.D. (1998). The sorption potential of octylphenol, a xenobiotic oestrogen, to suspended and bed-sediments collected from industrial and rural reaches on three English rivers. Sci. Total Environ. 210, 271-282.

KARICKHOFF, S.W., and MORRIS, K.R. (1985). Sorption dynamics of hydrophobic pollutants in sediment suspensions. Environ. Toxicol. Chem. 4, 469-479.

KEITH, L.H., GARRISON, A.W., ALLEN, F.R., CARTER, M.H., FLOYD, T.L., POPE, J.D., and THRUSTON, A.D., JR. (1975). Identification of organic compounds in drinking water from thirteen U.S. cities. Chem. Congr. North Am. Cont., pp. 329-373.

KING, W.D., DODDS, L., and ALLEN, A.C. (2000a). Relation between stillbirth and specific chlorination by-products in public water supplies. Environ. Health Pespect. 108, 883-886.

KING, W.D., and MARRETT, L.D. (1996). Case-control study of bladder cancer and chlorination by-products in treated water (Ontario, Canada). Cancer Causes Control 7, 596-604.

KING, W.D., MARRETT, L.D., and WOOLCOTT, C.G. (2000b). Case-control study of colon and rectal cancers and chlorination by-products in treated waters. Cancer Epidemiol. Biomater. Prevent. 9, 813-818.

KISO, Y., KON, T., KITAO, T., and NISHIMURA, K. (2001a). Rejection properties of alkyl phthalates with nanofiltration membranes. J. Membr. Sci. 182, 205-214.

KISO, Y., SUGIURA, Y., KITAO, T., and NISHIMURA, K. (2001b). Effects of hydrophobicity and molecular size on rejection of aromatic pesticides with nanofiltration membranes. J. Membr. Sci. 192, 1-10.

KNAPPE, D.R.U., MATSUI, Y., SNOEYINK, V.L., ROCHE, P., PRADOS, M.J., and BOURBIGOT, M.-M. (1998). Predicting the capacity of powder activated carbon for trace organic compounds in natural waters. Environ. Sci. Technol. 32, 1694-1698.

KOLPIN, D.W., FURLONG, E.T., MEYER, M.T., THURMAN, E.M., ZAUGG, S.D., BARBER, L.B., and BUXTON, H.T. (2002). Pharmaceuticals, hormones, and other organic waste contaminants in U.S. streams, 1999-2000: A national reconnaissance. Environ. Sci. Technol. 36, 1202-1211.

KOSAKA, K., YAMADA, H., MATSUI, S., and SHISHIDA, K. (2000). The effects of the co-existing compounds on the decomposition of micropollutants using the ozone-hydrogen peroxide process. Water Sci. Technol. 42, 353-361.

KOURAS, A., ZOUBOULIS, A., SAMARA, C., and KOUIMTZIS, T. (1998). Removal of pesticides from aqueous solutions by combined physicochemical processes-The behaviour of lindane. Environ. Pollut. 103, 193-202. 
KRAMER, V.J., MILES-RICHARDSON, S., PIERENS, S.L., and GIESY, J.P. (1998). Reproductive impairment and induction of alkaline-labile phosphate, a biomarker of estrogen exposure, in fathead minnows (Pimephales promelas) exposed to waterborne $17 \beta$-estradiol. Aquat. Toxicol. 40, $335-360$.

KRISHNAN, V., and SAFE, S. (1993). Polychlorinated biphenyls (PCBs), dibenzo-p-dioxins (PCDDs), and dibenzofurans (PCDFs) as antiestrogens in MCF-7 human breast cancer cells: Quantitative structure-activity relationships. Toxicol. Appl. Pharmacol. 120, 55-61.

LARSON, R.A., and WEBER, E.J. (1994). Reaction Mechanisms in Environmental Organic Chemistry. Boca Raton, FL: CRC Press.

LARSSON, D.G.J., HALLMAN, H., and FORLIN, L. (2000). More male fish near a pulp mill. Environ. Toxicol. Chem. 19, 2911-2917.

LEE, H.-B., and PEART, T.E. (1998). Determination of 17.beta.-estradiol and its metabolites in sewage effluent by solid-phase extraction and gas chromatography/mass spectrometry. J. AOAC Int. 81, 1209-1216.

LEUNG, K.S., and SEGAR, R.L. (1999). Adsorption of s-triazine herbicides in natural water by activated carbon. Am. Water Works Assoc. Ann Conf. Chicago, IL.

LEVIN, E., BURNS, J.F., and COLLINS, V.K. (1951). Estrogenic, androgenic, and gonadotropic activity in wheat-germ oil. Endocrinology 49, 289-301.

LIBER, K., GANGL, J.A., CORRY, T.D., HEINIS, L.J., and STAY, F.S. (1999). Lethality and bioaccumulation of 4nonylphenol in bluegill sunfish in littoral enclosures. Environ. Toxicol. Chem. 18, 394-400.

LOGAN, B.E. (2001). Assessing the outlook for perchlorate remediation. Promising technologies for treatment this widespread water contaminant are emerging. Environ. Sci. Technol. 35, 483A-487A.

LOPEZ, A., MASCOLO, G., TIRAVANTI, G., and PASSINO, R. (1997). Degradation of herbicides (ametryn and isoproturon) during water disinfection by means of two oxidants (hypochlorite and chlorine dioxide). Water Sci. Technol. 35, 129-136.

LYE, C.M., FRID, C.L.J., GILL, M.E., COOPER, D.W., and JONES, D.M. (1999). Estrogenic alklphenols in fish tissues, sediments, and waters from the U.K. tyne and tees estuaries. Environ. Sci. Technol. 33, 1009-1014.

MANN, R.M., and BODDY, M.R. (2000). Biodegradation of a nonylphenolethoxylate by the autochthonous microflora in lake water with observations on the influence of light. Chemosphere 41, 1361-1369.

MATSUI, S., and TAKIGAMI, H. (2000). State of endocrine disruptors research in Japan. AWWA 2000 Ann. Conf.-Sunday Workshop, Denver, CO.

MATSUMURA, Y., YAMABE, K., and TAKAHASHI, H.
(1985). The effects of hydrophilic structures of active-carbon on the adsorption of benzene and methanol vapors. Carbon 23, 263-271.

METZLER, M., and PFEIFFER, E. (1995). Effects of estrogens on microtubule polymerization in vitro: Correlation with estrogenicity. Environ. Health Pespect. 103, 21-22.

MILES-RICHARDSON, S.R., PIERENS, S.L., NICHOLS, K.M., KRAMER, V.J., SNYDER, E.M., SNYDER, S.A., RENDER, J.A., FITZGERALD, S.D., and GIESY, J.P. (1999). Effects of waterborne exposure to 4-nonylphenoland nonylphenol ethoxylate on secondary sex characteristics and gonads of fathead minnows (Pimephales promelas). Environ. Res. Sect. A, 80, S122-S137.

MILLINGTON, A.J., FRANCIS, C.M., and MCKEOWN, N.R. (1964). Wether bioassay of annual pasture legumes. II. The estrogenic activity of nine strains of Trifolium subterraneum L. Aust. J. Agr. Res. 15, 527-536.

MILTNER, R.J., BAKER, D.B., SPETH, T.F., and FRONK, C.A. (1989). Treatment of seasonal pesticides in surface waters. J. Am. Water Works Assoc. 81, 43-52.

MOFIDI, A.A., COFFEY, B.M., CHOU, C.I., LUANG, S., and GREEN, J.F. (2000). Using ultraviolet light to achieve multiple water quality objectives. AWWA WQTC Conference, Salt Lake City, UT.

MUELLER, G.C., and KIM, U.H. (1978). Displacement of estradiol from estrogen receptors by simple alkylphenols. Endocrinology 102, 1429-1435.

MUNKITTRICK, K.R., SERVOS, M.R., CAREY, J.H., and VAN DER KRAAK, G.J. (1997). Environmental impacts of pulp and paper wastewater: Evidence for a reduction in environmental effects at North American pulp mills since 1992. Water Sci. Technol. 35, 329-338.

NAJM, I.N., SNOEYINK, V.L., LYKINS, B.W., and ADAMS, J.Q. (1991a). Using powdered activated carbon-A criticalreview. J. Am. Water Works Assoc. 83, 65-76.

NAJM, I.N., SNOEYINK, V.L., and RICHARD, Y. (1991b). Effect of initial concentration of a soc in natural-water on its adsorption by activated carbon. J. Am. Water Works Assoc. 83, 57-63.

NEAMTU, M., SIMINICEANU, I., and KETTRUP, A. (2000). Kinetics of nitromusk compounds degradation in water by ultraviolet radiation and hydrogen peroxide. Chemosphere 40, 1407-1410.

NEWCOMBE, G. (1999). Charge vs. porosity-Some influences on the adsorption of natural organic matter (NOM) by activated carbon. Water Sci. Technol. 40, 191-198.

NEWCOMBE, G., DRIKAS, M., ASSEMI, S., and BECKETT, R. (1997a). Influence of characterized NOM on activated carbon adsorptioni: 1. Characterization of concentrated reservoir water. Water Res. 31, 965-972.

NEWCOMBE, G., DRIKAS, M., and HAYES, R. (1997b). Influence of characterized NOM on activated carbon adsorp- 
tion: 2. Effect on pore volume distribution and adsorption of MIB. Water Res. 31, 1065-1073.

OUELLET, M., BONIN, J., RODRIGUE, J., DESGRANGES, J.J.-L., and LAIR, S. (1997). Hindlimb deformities (ectromelia, extrodctyly) in free-living anurans from agricultural habitats. J. Wildlife Dis. 33, 95-104.

OZAKI, H., and LI, H.F. (2002). Rejection of organic compounds by ultra-low pressure reverse osmosis membrane. Water Res. 36, 123-130.

PANTER, G.H., THOMPSON, R.S., and SUMPTER, J.P. (1998). Adverse reproductive effects in male fathead minnows (Pimephales promelas) exposed to environmentallyrelevant concentrations of the natural oestrogens, oestradiol and oestrone. Aquat. Toxicol. 42, 243-253.

PENDLETON, P., WONG, S.H., SCHUMANN, R., LEVAY, G., DENOYEL, R., and ROUQUEROL, J. (1997). Properties of activated carbon controlling 2-methylisoborneol adsorption. Carbon. 35, 1141-1149.

PIRBAZARI, M., BADRIYHA, B.N., KIM, S.H., and MILTNER, R.J. (1992). Evaluating GAC adsorbers for the removal of PCBs and toxaphene. J. Am. Water Works Assoc. 84, 83-90.

PURSOM, C.E., HARDIMAN, P.A., BYE, V.J., ENO, N.C., TYLER, C.R., and SUMPTER, J.P. (1994). Estrogenic effects of effluents from sewage treatment works. Chem. Ecol. 8, 275-285.

PUTSCHEW, A., WISCHNACK, S., and JEKEL, M. (2000). Occurrence of triiodinated X-ray contrast agents in the aquatic environment. Sci. Total Environ. 255, 129-134.

RAVACHA, C., and BLITS, R. (1985). The different reactionmechanisms by which chlorine and chlorine dioxide react with polycyclic aromatic-hydrocarbons (PAH) in water. $\mathrm{Wa}$ ter Res. 19, 1273-1281.

REBHUN, M., and LURIE, M. (1993). Control of organic-matter by coagulation and floc separation. Water Sci. Technol. 27, 1-20.

REBHUN, M., MEIR, S., and LAOR, Y. (1998). Using dissolved humic acid to remove hydrophobic contaminants from water by complexation-flocculation process. Environ. Sci. Technol. 32, 981-986.

RENNER, R. (1998). Human estrogens linked to endocrine disruption. Environ. Sci. Technol. 32, 8A.

ROBECK, G.G., DOSTAL, K.A., COHEN, J.M., and KRIESSL, J.F. (1965). Effectiveness of water treatment processes in pesticide removal. J. Am Water Works Assoc. 57, 181-200.

ROUTLEDGE, E.J., SHEAHAN, D., DESBROW, C., BRIGHTY, G.C., WALDOCK, M., and SUMPTER, J.P. (1998). Identification of estrogenic chemicals in STW effluent. 2. In vivo responses in trout and roach. Environ. Toxicol. Chem. 32, 1559-1565.

ROUTLEDGE, E.J., and SUMPTER, J.P. (1997). Structural features of alkylphenolic chemicals associated with estrogenic activity. J. Biol. Chem. 272, 3280-3288.

RUDEL, R. (1997). Predicting health effects of exposures to compounds with estrogenic activity: Methodological issues. Environ. Health Perspect. 105, 655-663.

RUMSEY, T.S., and HAMMOND, A.C. (1990). Effects of intake level on metabolic response to estrogenic growth promoters in beef steers. J. Anim. Sci. 68, 4310-4318.

SACHER, F., HAIST-GULDE, B., BRAUCH, H.-J., PREUß, G., WILME, U., ZULLEI-SEIBERT, N., MEISENHEIMER, M., WELSCH, H., and TERNES, T.A. (2000). Behavior of selected pharmaceuticals during drinking water treatment. 219th ACS Nat. Meeting, San Francisco, CA, pp. 116-118.

SAFE, S.H., and GAIDO, K. (1998). Phytoestrogens and anthropogenic estrogenic compounds. Environ. Toxicol. Chem. 17, 119-126.

SCHUELER, F.W. (1946). Sex-hormonal action and chemical constitution. Science 103, 221-223.

SEDLAK, D.L., and PINKTON, K.E. (2001). Factors affecting the concentrations of pharmaceuticals released to the aquatic environment. Water Res. 120, 56-64.

SETCHELL, K.D.R., GOSSELIN, S.J., WELSH, M.B., JOHNSTON, J.O., BALISTRERI, W.F., KRAMER, L.W., DRESSER, B.L., and TARR, M.J. (1987). Dietary estrogens-A probable cause of infertility and liver disease in captive cheetahs. Gastroenterology 93, 225-233.

SHARPE, R.M., and SKAKKEBAEK, N.E. (1993). Are oestrogens involved in falling sperm counts and disorders of the male reproductive tract? Lancet 341, 1392-1395.

SHORE, L.S., GUREVITZ, M., and SHEMESH, M. (1993). Estrogen as an environmental pollutant. Bull. Environ. Contam. Toxicol. 51, 361-366.

SLUCZEWSKI, A., and ROTH, P. (1948). Effects of androgenic and estrogenic compounds on the experimental metamorphoses of amphibians. Gynecol. Obstet. 47, 164-176.

SNYDER, S.A., KELLY, K.L., GRANGE, A.H., SOVOCOOL, G.W., SNYDER, E.M., and GIESY, J.P. (2001a). Pharmaceuticals and personal care products in the waters of Lake Mead, Nevada. In C.G. Daughton and T.L. Jones-Lepp, Eds., Pharmaceuticals and Personal Care Products in the Environment: Scientific and Regulatory Issues. Washington, DC: American Chemical Society, pp. 116-140.

SNYDER, S.A., KEITH, T.L., PIERENS, S.L., SNYDER, E.M., and GIESY, J.P. (2001b). Bioconcentration of nonylphenol in fathead minnows (Pimephalas promelas). Chemosphere 44, 1697-1702.

SNYDER, S.A., KEITH, T.L., VERBRUGGE, D.A., SNYDER, E.M., GROSS, T.S., KANNAN, K., and GIESY, J.P. (1999). Analytical methods for detection of selected estrogenic compounds in aqueous mixtures. Environ. Sci. Technol. 33, 2814-2820.

SNYDER, S.A., SNYDER, E., VILLENEUVE, D., KURUN- 
THACHALAM, K., VILLALOBROS, A., BLANKENSHIP, A., and GIESY, J. (2000). Instrumental and bioanalytical measures of endocrine disruptors in water. In L.H. Keith, T.L. Jones-Lepp, and L.L. Needham, Eds., Analysis of Environmental Endocrine Disruptors. Washington, DC: American Chemical Society, pp. 73-95.

SNYDER, S.A., VILLENEUVE, D.L., SNYDER, E.M., and GIESY, J.P. (2001c). Identification and quantification of estrogen receptor agonists in wastewater effluents. Environ. Sci. Technol. 35, 3620-3625.

SOWER, S.A., SCHRECK, C.B., and EVENSON, M. (1983). Effects of steroids and steroid antagonists on growth, gonadal development, and RNA/DNA ratios in juvenile steelhead trout. Aquaculture 32, 243-254.

SPARLING, D.W. (2000). Effects of altosid and abate-4e on deformities and survival in southern leopard frogs under semi-natural conditions. J. Iowa Acad. Sci. 107, 90-91.

SPETH, T.F. (1993). Glyphosate removal from drinking-water. J. Environ. Eng. -ASCE 119(6), 1139-1157.

SPETH, T.F., and ADAMS, J.Q. (1993). GAC and air stripping design support for the Safe Drinking Water Act. In R. Clark and R.S. Summers, Eds., Strategies and Technologies for Meeting SDWA Requirements. Ann Arbor, MI: Lewis Publishers, Inc., pp. 47-89.

SPETH, T.F., and MILTNER, R.J. (1998). Adsorption capacity of GAC for synthetic organics-Part II. J. Am. Water Works Assoc. 90(4), 171-174.

STEINER, J., and SINGLEY, J.E. (1979). Methoxychlor removal from potable water. J. Am. Water Works Assoc. 71, 284-286.

STONE, R. (1994). Environmental estrogens stir debate. Science 265, 308-310.

STROUD, S.W. (1940). Metabolism of the parent compounds of some of the simpler synthetic estrogenic hydrocarbons. $J$. Endocrinol. 2, 55-62.

STUMM-ZOLLINGER, E., and FAIR, G.M. (1965). Biodegradation of steroid hormones. J. Water Pollut. Cont. Fed. 37, 1506-1510.

STUMPF, M., TERNES, T.A., ROLF-DIETER, W., RODRIGUES, S.V., and BAUMANN, W. (1999). Polar drug residues in sewage and natural waters in the state of Rio de Janeiro, Brazil. Sci. Total Environ. 225, 135-141.

TABAK, H.H., BLOOMHUFF, R.N., and BUNCH, R.L. (1981). Steroid hormones as water pollutants II. Studies on the persistence and stability of natural urinary and synthetic ovulation-inhibiting hormones in untreated and treated wastewaters. Dev. Ind. Microbiol. 22, 497-519.

TABAK, H.H., and BUNCH, R.L. (1970). Steroid hormones as water pollutants. I. Metabolism of natural and synthetic ovulation-inhibiting hormones by microorganisms of activated sludge and primary settled sewage. Dev. Ind. Microbiol. 11, 367-376.
TANGHE, T., and VERSTRAETE, W. (2001). Adsorption of nonylphenol onto granular activated carbon. Water Air Soil Pollut. 131, 61-72.

TERNES, T.A. (1998). Occurrence of drugs in German sewage treatment plants and rivers. Water Res. 32, 3245-3260.

TERNES, T.A. (2001). Analytical methods for the determination of pharmaceuticals in aqueous environmental samples. Trends Anal. Chem. 20, 419-434.

TERNES, T.A., HIRSCH, R., MUELLER, J., and HABERER, K. (1998). Methods for the determination of neutral drugs as well as betablockers and $\beta_{2}$-sympathomimetics in aqueous matrices using GC/MS and LC/MS/MS. Fresenius' J. Anal. Chem. 362, 329-340.

TERNES, T.A., KRECKEL, P., and MEULLER, J. (1999a). Behaviour and occurrence of estrogens in municipal sewage treatment plants-II. Aerobic batch experiments with activated sludge. Sci. Total Environ. 225, 91-99.

TERNES, T.A., STUMPF, M., MUELLER, J., HABERER, K., WILKEN, R.D., and SERVOS, M. (1999b). Behavior and occurrence of estrogens in municipal sewage treatment plants-I. Investigationsin Germany, Canada and Brazil. Sci. Total Environ. 225, 81-90.

TOLLS, J. (2001). Sorption of veterinary pharmaceuticals in soils: A review. Environ. Sci. Technol. 35, 3397-3406.

TRATNYEK, P.G., and HOIGNE, J. (1994). Kinetics of reactions of chlorine dioxide $\left(\mathrm{OCl}_{2}\right)$ in water. 2. Quantitative structure-activity-relationships for phenolic-compounds. Water Res. 28, 57-66.

ULUDAG, Y., OZBELGE, H.O., and YILMAZ, L. (1997). Removal of mercury from aqueous solutions via polymer-enhanced ultrafiltration. J. Membr. Sci. 129, 93-99.

URASE, T., SALEQUZZAMAN, M., KOBAYASHI, S., MATSUO, T., YAMAMOTO, K., and SUZUKI, N. (1997). Effect of high concentration of organic and inorganic matters in landfill leachate on the treatment of heavy metals in very low concentration level. Water Sci. Technol. 36, 349-356.

URBANSKY, E.T. (2000). Perchlorate in the environment. In H.S. Rosenkranz, Ed., Environmental Science Research, New York: Kluwer Academic/Plenum Publishers, p. 299.

VAN DER BRUGGEN, B., EVERAERT, K., WILMS, D., and VANDECASTEELE, C. (2001). Application of nanofiltration for removal of pesticides, nitrate and hardness from ground water: Rejection properties and economic evaluation. J. Membr. Sci. 193, 239-248.

VRIJENHOEK, E.M., and WAYPA, J.J. (2000). Arsenic removal from drinking water by a "loose" nanofiltration membrane. Desalination 130, 265-277.

WALKER, B.S., and JANNEY, J.C. (1930). Estrogenic substances. II. Analysis of plant sources. Endocrinology 14, 389-392. 
WANG, C.K., and LEE, S.E. (1997). Evaluation of granular activated carbon adsorber design criteria for removal of organics based on pilot and small-scale studies. Water Sci. Technol. 35, 227-234.

WANG, H.-C., EATON, A., and NARLOCH, B. (2002). National Assessment of Perchlorate Contamination Occurrence. Denver, CO: Am Water Works Assoc. Res. Found.

WEIL, I.W., and MORRIS, J.C. (1974). Dynamics of breakpoint chlorination. In Chemistry of Water Treatment, Supply, and Distribution. Ann Arbor: Science Publishers.

WELCH, R.M., LEVIN, W., and CONNEY, A.H. (1969). Estrogenic action of DDT and its analogs. Toxicol. Appl. Pharmacol. 14, 358-367.

WEST, P. (2000). State of endocrine disruptors and the water industry. AWWA 2000 Annual Conference, Sunday Workshop, Denver, CO.

WHITE, R., JOBLING, S., HOARE, S.A., SUMPTER, J.P., and PARKER, M.G. (1994). Environmentally persistent alkylphenolic compounds are estrogenic. Endocrinology 135, 175-182.

WRENN, T.R., WOOD, J.R., FRIES, G.F., and BITMAN, J. (1970). Tests of estrogenicity in rats fed low levels of o,p'DDT. Bull. Environ. Contam. Toxicol. 5, 61-66.

WU, S.H., and PENDLETON, P. (2001). Adsorption of anionic surfactant by activated carbon: Effects of surface chemistry, ionic strength, and hydrophobicity. J. Colloid Interface Sci. 243, 306-315.
YOON, Y., AMY, G., CHO, J., HER, N., and PELLEGRINO, J. (2002b). Transport of perchlorate (ClO4-) through NF and UF membranes. Desalination 147, 11-17.

YOON, Y., AMY, G., CHO, J., and PELLEGRINO, J. (2002a). Systematic bench-scale assessment of perchlorate $\left(\mathrm{ClO}_{4}{ }^{-}\right)$ rejection mechanisms by nanofiltration and ultrafiltration membranes. Sep. Sci. Technol., in revision.

YOON, Y., AMY, G., LIANG, S., and YOON, J. (2001). Determination of dominant potential mechanisms for perchlorate rejection by negatively charged nanofiltration and ultrafiltration membranes. AWWA Membrane Technology Conference, San Antonio, TX.

YOON, Y., WESTERHOFF, P., SNYDER, S., and ESPARZA, M. (2003). HPLC-fluorescence detection and adsorption of bisphenol A, $17 \beta$-estradiol, and $17 \alpha$-ethynyl estradiol on powdered activated carbon. Water Res. 37, 3530-3537.

YOUSSEF, A.M., GHAZY, T.M., and ELNABARAWY, T. (1982). Moisture sorption by modified-activated carbons. Carbon 20, 113-116.

ZACHAREWSKI, T. (1997). In vitro bioassays for assessing estrogenic substances. Environ. Sci. Technol. 31, 613623.

ZHANG, T.C., and EMARY, S.C. (1999). Jar tests for evaluation of atrazine removal at drinking water treatment plants. Environ. Eng. Sci. 16, 417-432. 